OPEN ACCESS

Edited by: Jeremiah Grahm Plass-Johnson, Technical University of Denmark,

Denmark

Reviewed by:

Hajime Kayanne,

University of Tokyo, Japan Lech Kotwicki,

Institute of Oceanology (PAN), Poland

*Correspondence:

Thomas Mann

thomas.mann@leibniz-zmt.de

Specialty section: This article was submitted to

Marine Ecosystem Ecology, a section of the journa

Frontiers in Marine Science

Received: 14 February 2017 Accepted: 28 April 2017

Published: 29 May 2017

Citation:

Kench PS and Mann T (2017) Reef Island Evolution and Dynamics: Insights from the Indian and Pacific

Oceans and Perspectives for the

Spermonde Archipelago.

Front. Mar. Sci. 4:145

doi: 10.3389/fmars.2017.00145

\section{Reef Island Evolution and Dynamics: Insights from the Indian and Pacific Oceans and Perspectives for the Spermonde Archipelago}

\author{
Paul S. Kench ${ }^{1}$ and Thomas Mann ${ }^{2 *}$ \\ ${ }^{1}$ School of Environment, The University of Auckland, Auckland, New Zealand, ${ }^{2}$ Leibniz Centre for Tropical Marine Research \\ (ZMT), Bremen, Germany
}

Along southwestern Sulawesi, Indonesia, the Spermonde Archipelago comprises some 120 islands of variable size and degree of anthropogenic modification. Comparable to adjacent areas in Southeast Asia, the Spermonde Archipelago is characterized by the congregation of a naturally high marine biodiversity and, at the same time, a high population density influencing the surrounding environmental conditions. As a consequence, during the last decades, research projects that have been carried out in the Spermonde mainly focused on social, ecological, political and economic interactions. However, geological and geomorphological aspects of the coral reef islands are less well understood and there have been few studies undertaken since the pioneering work of Umbgrove, Kuenen, and Verstappen in the Indonesian archipelago in the early to mid-twentieth century. Here we review the existing studies, with a focus on the Spermonde Archipelago, and reconcile them with more recent works on reef island evolution and dynamics from the Indian and Pacific Oceans. This synthesis shows that reef islands in the Spermonde Archipelago are well suited for geomorphological investigations, and provides perspectives for future reef island research in that area that will have global interest. We identify four research priorities: (1) To identify the timing and chronology of island formation; (2) Improved understanding of carbonate budgets and sediment generation that contribute to island building; (3) Document morphological changes in reef islands at seasonal to decadal timescales, and; (4) Quantify the process regime that drives sediment transport and island change with particular focus on the role of different monsoon seasons.

Keywords: carbonate sediments, Holocene, sea level, coral reefs, biodiversity, Indonesia, Southeast Asia

\section{INTRODUCTION}

The Indonesian archipelago comprises more than 17,000 islands located among the world's most diverse and abundant coral reef systems. While the majority of Indonesia's 260 million population inhabit the larger islands of Java, Sumatra, Borneo and Sulawesi, thousands of smaller reef islands are located within the adjacent tropical seas. These smaller islands and their coral reefs are rich in marine biodiversity and also provide habitable land for coastal communities. Despite the large number of reef islands and their importance to coastal communities, there have been few 
studies of the geological characteristics, evolution and dynamics of reef islands in Indonesia since pioneering and detailed investigations in the early twentieth century (Umbgrove, 1929, 1930; Kuenen, 1934). Addressing these gaps in knowledge is paramount for understanding the ongoing physical adjustment and management of islands in the archipelago, which are faced with rapid global climatic changes, sea-level rise and increased anthropogenic pressure.

Reef islands throughout the Indonesian archipelago are typically low-lying, rarely being more than $2-3 \mathrm{~m}$ above mean sea level, and are composed of calcareous sediments derived from the broken down remains of corals, coralline algae, and other carbonate secreting organisms from adjacent coral reef environments. Due to their low elevation, small size and detrital sediment composition, reef islands are widely considered among the most geomorphically sensitive landforms on earth to changes in sea level, wave processes, sediment supply and anthropogenic impacts. Indeed, numerous reports suggest reef islands will be submerged by rising seas and be eroded away (Dickinson, 1999; Hubbard et al., 2014; Pala, 2014), with the metaphor of "sinking islands" becoming a commonly held perception in climate change debates (Roy and Connell, 1991; Leatherman and Beller-Simms, 1997; Barnett and Adger, 2003; Ferris et al., 2011). In extreme scenarios total loss of islands are forecast, rendering island inhabitants the first environmental refugees of climate change (Klepp, 2014) with forced relocation of communities viewed as inevitable over the coming decades (Green, 2016). In the context of the Indonesian archipelago the availability of larger land masses might reasonably afford adaptation solutions via relocation. However, physical change or loss of islands represents substantial alterations to marine processes and resources that need to be more fully understood. While international debate is dominated by extreme scenarios of island loss, changes in island stability (erosion/accretion) and flooding as a result of increased sea level and changes in wave processes and storm frequency pose real and serious consequences for island communities that need to be managed at short to medium timescales. A number of studies have examined the social and economic issues related to coral reef dependent livelihoods in Indonesia, the resilience of marine communities and the management of coastal ecosystems and their resources (e.g., Ferse et al., 2012). In contrast, few studies have explored anthropogenic impacts on processes that influence physical change in the islands.

In contrast to narratives of island sinking, recent studies have emerged, which present evidence that reef islands are robust landforms that react dynamically to changes in oceanic and climatic boundary conditions across seasonal to millennial timescales (e.g., Kench and Brander, 2006b; Webb and Kench, 2010; McLean and Kench, 2015). Collectively, these studies show that physical island change is an ongoing process on reef islands with differential island erosion and accretion resulting in island migration on reef platforms and with many islands increasing in area. These studies suggest that islands are likely to persist over the twenty first century and beyond (McLean and Kench, 2015). The likely persistence of islands into the foreseeable future places a premium on improved knowledge of both the environmental challenges confronting small reef islands and understanding of the future trajectories of reef islands. In particular, it is necessary to develop robust knowledge of the environmental controls that govern both the formation of islands and their ongoing morphodynamics at seasonal to decadal timeframes.

In recent decades considerable new insights have been generated on the environmental controls on island evolution and dynamics from Pacific and Indian Ocean reef systems. In this review we examine current knowledge of reef island formation and dynamics and apply these insights to the Spermonde Archipelago, Indonesia. Based on this synthesis and observations by the authors, we highlight future reef island research priorities in the archipelago.

\section{THE SPERMONDE ARCHIPELAGO}

The Spermonde Archipelago is located within the Coral Triangle, between the southern arc of Sulawesi in central Indonesia, and the Strait of Makassar $\left(4^{\circ} 00^{\prime} S-6^{\circ} 00^{\prime} S\right.$ and $119^{\circ} 00^{\prime} \mathrm{E}-119^{\circ} 30^{\prime} \mathrm{E}$; Figure 1). Geologically, the basement of South Sulawesi consists mainly of metamorphic, volcanic and sedimentary rocks emplaced during the early to late Cretaceous (van Bemmelen, 1949; Hamilton, 1979; Wakita and Bambang, 1994) and subsequently covered by Paleogene to Neogene volcanics and clastic sediments (van Bemmelen, 1949; Katili, 1978; Bergman et al., 1996). Sulawesi belongs to an area that has a complex tectonic setting (Hall and Blundell, 1996). The northern sector of the western Sulawesi volcanic arc comprises abundant active lateral and thrust faults (Bird, 2003). However, South Sulawesi, encompassing the Spermonde Archipelago is believed to be tectonically stable (Sasajima et al., 1980; Hall, 1997; Walpersdorf et al., 1998; Prasetya et al., 2001). Consequently, the shallow-marine platform that forms the immediate basement of the archipelago consists of undeformed Tertiary carbonate sediments (Bergman et al., 1996).

A representative cross-section from the mainland to barrier reef edge (east to west) highlights four broad geomorphic units (De Klerk, 1982): (i) the volcanic hinterland with the extinct volcano Lompo Batang; (ii) the Piedmont at the foot of the volcanic complex comprising Tertiary volcano-clastic sediments; (iii) the alluvial coastal plain where Makassar is situated, and (iv) the shelf, comprising the islands of Spermonde.

The mesotrophic carbonate shelf is between 30 and $50 \mathrm{~km}$ wide, covers an area of $\sim 16,000 \mathrm{~km}^{2}$ and is separated from the Strait of Makassar in the west by a discontinuous barrier reef. Water depths decrease rapidly from more than $200 \mathrm{~m}$ in the Makassar Strait to $\sim 60 \mathrm{~m}$ at the shelf margin (Renema and Troelstra, 2001; Renema, 2002). The Spermonde Shelf bordering the coastal plain is characterized by the occurrence of numerous patchy coral-reef complexes in near-parallel arrangement to the coastline, and which form the foundation of reef islands (Umbgrove, 1929; Wijsman-Best et al., 1981; De Klerk, 1982; Renema, 2002). The coastline along the Spermonde Shelf itself does not comprise fringing reefs (De Klerk, 1982). The archipelago comprises some 120 coral reef islands that formed on top of localized patch reefs within the shallow-marine carbonate platform (Figure 2). 


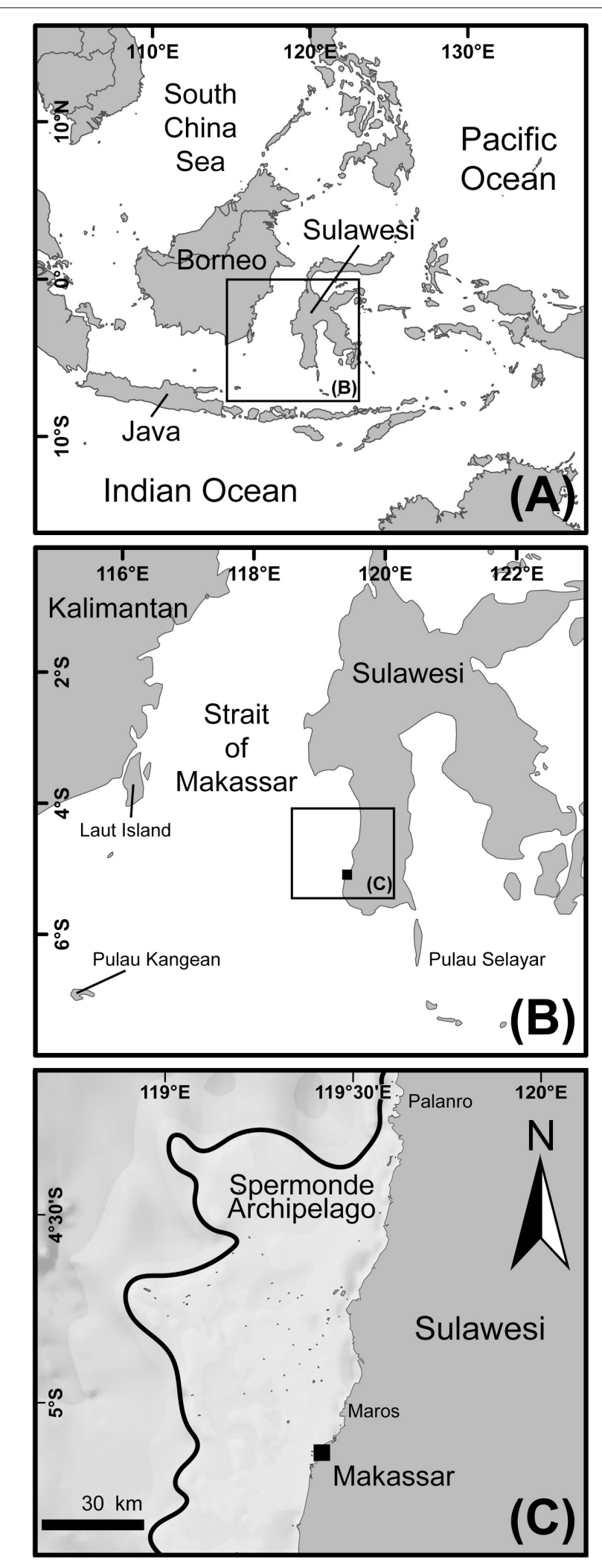

FIGURE 1 | The Indonesian archipelago and the Spermonde Shelf. (A) Location of Sulawesi in central Indonesia between the Indian and Pacific

(Continued)
FIGURE 1 | Continued

oceans. (B) Sulawesi and Kalimantan in the central part of Indonesia and separated by the Strait of Makassar. (C) The shallow carbonate platform of the Spermonde Archipelago situated at the western coastline of southwest Sulawesi with a general bathymetric chart (Source: Esri, GEBCO, NOAA, National Geographic, DeLorme, HERE, Geonames.org, and other contributors). Thick black line indicates the shelf break.

Riverine sediment and nutrient input onto the Spermonde Shelf comes from the two major rivers in that area, the Jene Berang to the south of Makassar, and Maros to the north of the capital city (Renema and Troelstra, 2001; Renema, 2002). The majority of terrestrial sediment is discharged from the Jene Berang (De Klerk, 1982) with the resulting sediment plume being deflected toward the south during the fair weather season (Renema, 2002). Despite the proximity of Makassar, which contains $\sim 2.75$ million people, fluvial influence in terms of visibility and nutrient levels is believed to be limited to the foreshore and proximal shoreface ( $<4 \mathrm{~km}$ from the coast) (Storm, 1989; Erftemeijer, 1993). The supply of clastic sediment to the foreshore is thought to account for the absence of fringing reefs along the coast.

\section{Oceanographic Regime}

Tides of the Makassar Strait are mixed semi-diurnal, with significant diurnal inequality. The area is characterized as micro-tidal with mean amplitudes of the semi-diurnal $\mathrm{M}_{2}$ and diurnal $\mathrm{K}_{1} \sim 0.2$ and $0.3 \mathrm{~m}$, respectively (Ray et al., 2005). The currents and wave processes in the Makassar Strait and Spermonde Archipelago are strongly modulated by marked reversals in monsoon winds toward the southeast during the boreal winter (Dec-Feb) and northwest in summer (Jun-Aug). The Makassar Strait also acts as the major conduit of the Indonesian Throughflow (ITF), the arterial pathway connecting the Pacific and Indian oceans, and which plays a critical role in the coupled ocean and climate system (Gordon et al., 1999, 2003; Gordon, 2005; Sprintall and Revelard, 2014). The ITF dynamics in the Makassar Strait are modulated by the monsoonal wind patterns. During the boreal winter (Dec-Feb) southeast winds enforce the flow of waters from the North Pacific through the Strait. However, during the boreal summer (Jun-Aug) northwest winds push water from the Java Sea into the southern part of Makassar Strait generating a northward pressure head that impedes the ITF. The monsoonally forced variation in ITF also imparts seasonal differences in sea surface salinity in the vicinity of the Spermonde Archipelago from lower salinity during the southeast and higher salinity during northwest monsoons (Gordon, 2005).

Analysis of WW3 data across a 30 year window (1980-2010) highlights spatial and seasonal variations in wave energy in the region of the Spermonde Archipelago (Figures 3, 4). In general the area can be characterized as having a low to moderate energy wave regime. Larger wave heights (mean $H_{s}=0.8 \mathrm{~m}$ ) are present during the dry season (May-October) with a mean direction of $132^{\circ}$, with periods typically below $T_{s}=5 \mathrm{~s}$. The wave regime is directly influenced by the moderate ESE winds (mean $=6.1$ 


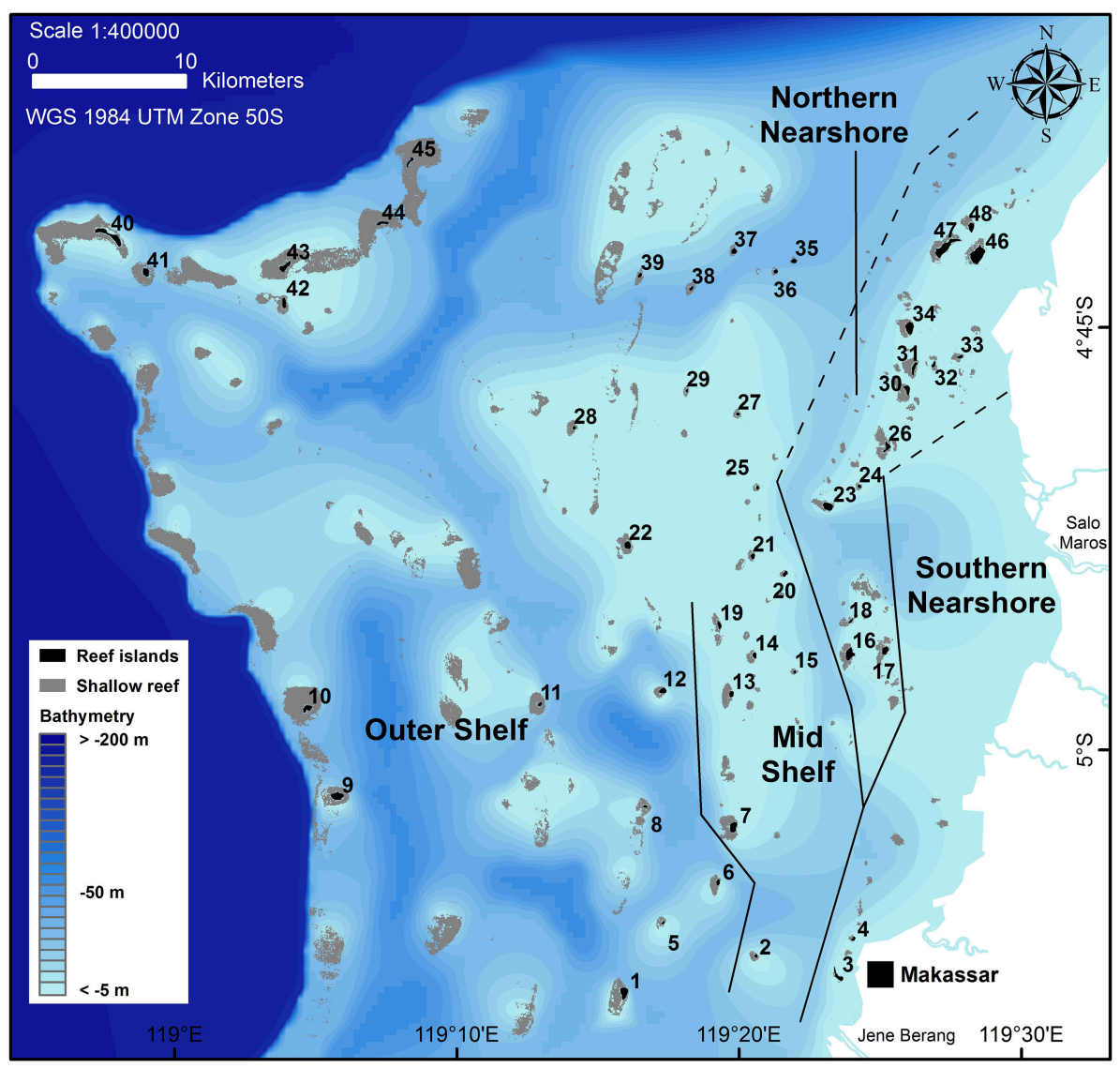

FIGURE 2 | Bathymetric map of the Spermonde Archipelago showing all named islands and larger reef structures. At the shelf break, the water depth increases to about $200 \mathrm{~m}$. Zonation follows Renema (2002) with northern extensions inferred by the authors. Reef island numbers refer to islands names in Table 1. A Supplementary Image 1 of this figure has been prepared without island numbers and shelf zonation. Bathymetry was reconstructed based on Landsat ETM data (Acquisition year 2002) and Renema (2002).

$\mathrm{ms}^{-1}$ from $124^{\circ}$ ) that prevail in this period. The wet season (November-April) is characterized by lighter NNW winds (mean $\left.=2.77 \mathrm{~ms}^{-1}\right)$ with contrasting direction $\left(238^{\circ}\right)$ and smaller wave heights (mean $H_{s}=0.53 \mathrm{~m}$ ) that are characterized by short periods between 5 and $6 \mathrm{~s}$ (Figure 4). The peak of the dry season occurs between July and August and is the most energetic period of the year for wave activity, associated with $H_{s}=1 \pm 0.25 \mathrm{~m}$ (Figure 4). A period of higher wave energy also persists through the wet season, during January and February, associated with $H_{s}$ $\approx 0.75 \pm 0.45 \mathrm{~m}$, indicating moderate but highly variably wave energy. Months occurring between peak seasons (March and November) are characterized by light variable wind and minimal wave energy $\left(H_{s}=0.4 \pm 0.25 \mathrm{~m}\right)$. Of note, the orientation of the Sulawesi mainland has the effect of moderating the influence of the easterly wind patterns on the wave process regime within the archipelago.

\section{Anthropogenic Influence}

Approximately 50 islands of the Spermonde Archipelago are inhabited and collectively host 50,000 people (Glaser et al., 2015). Many of the inhabited islands are intensely developed and numerous shoreline structures are evident, serving to disrupt natural shoreline processes. Furthermore, environmental data from the Spermonde indicate that human activities strongly affect coral reef ecosystem functioning, either via direct and acute stresses such as destructive fishing techniques, or due to chronic threats resulting from land-based pollution (Jompa, 1996). A detailed evaluation of the different anthropogenic impacts on coral biodiversity in the Spermonde Archipelago is provided by Edinger et al. (1998). Their results show that on those reefs which are subject to mechanical anchor damage or ship groundings, the strongest signs of degradation can be recorded in shallow water depths $(3 \mathrm{~m})$, leading to a reduction of within-habitat species diversity up to $50 \%$ compared to reefs which are less affected by such anthropogenic activities. Chronic stress such as the disposal of untreated sewage and industrial waste, agricultural runoff and riverine sediment input resulted in a loss of coral diversity between 30 and $60 \%$ both in shallow and deeper $(10 \mathrm{~m})$ waters. Of particular importance, a comparison to an earlier study by Moll (1983) revealed a reduction in coral diversity of $25 \%$ around two islands in the Spermonde Archipelago (Pulau Samalona and Pulau Barrang Lompo) between 1980 and 1995. The combination 


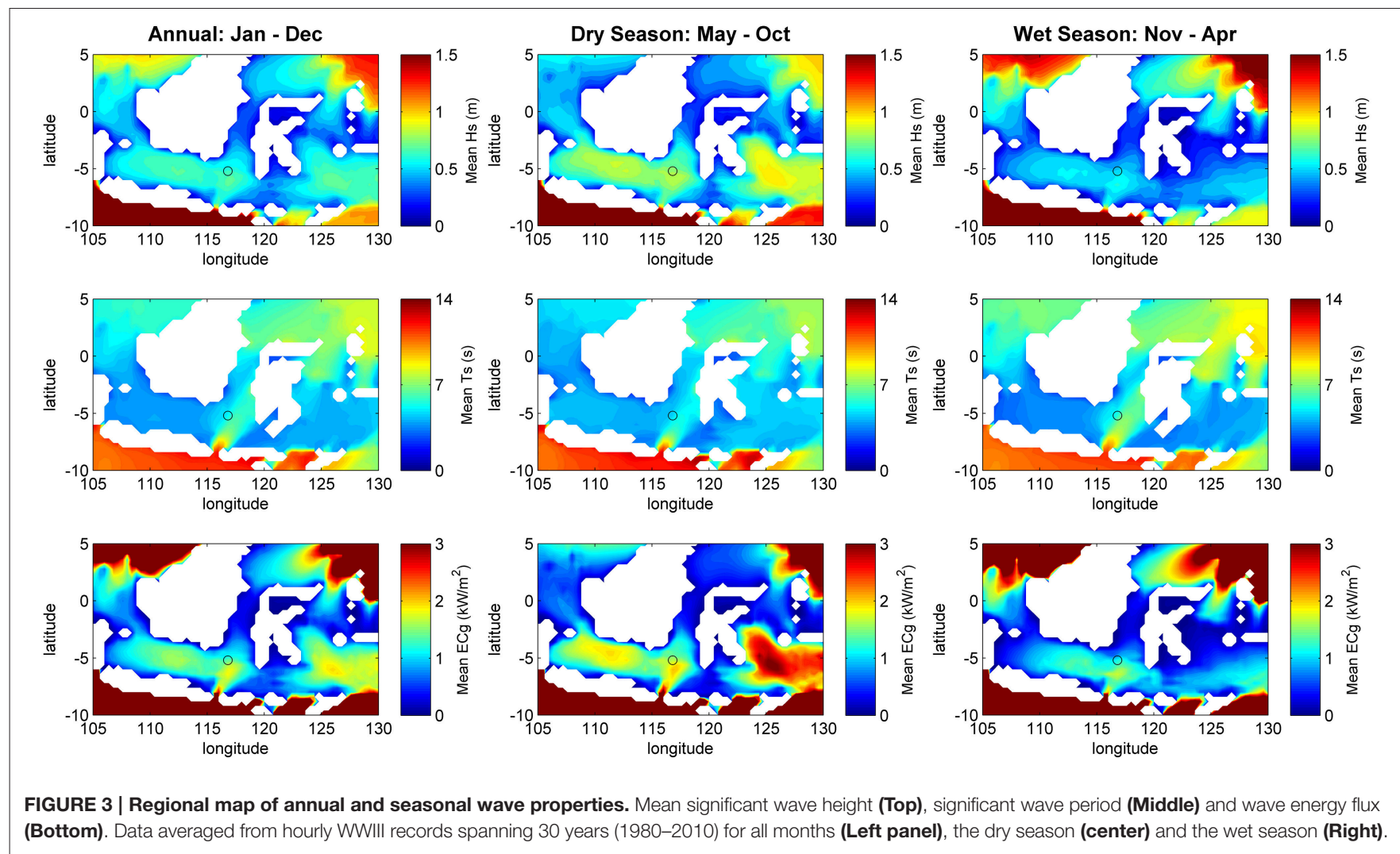

of intense coastal urbanization and the increasing pressure on the environment additionally drives a number of social-ecological feedbacks (Ferrol-Schulte et al., 2015; Glaser et al., 2015).

In a recent study by Haya and Fujii (2017), analyses of remote sensing data and in situ coral reef surveys revealed a substantial decline in live coral cover within coral reef habitats in the shallow waters $(<10 \mathrm{~m})$ of the Spermonde Archipelago. Whereas in 1994 the archipelago was characterized by about $72 \%$ of living coral cover, in 2002 this value decreased to $64 \%$ and further reduced to $39 \%$ in 2014 . The degradation of living corals within reef habitats is explained by destructive fishing techniques and increasing concentrations of total suspended matter, especially in the nearshore zone (Figure 2). Direct and acute stressors are compounded by the proximity of Makassar (Ujung Pandang), the largest metropolitan city in Sulawesi. As a consequence the marine systems of the archipelago that influence island formation and change have an indelible human impact.

\section{REEF ISLANDS IN THE SPERMONDE ARCHIPELAGO}

There are $\sim 120$ islands in the Spermonde Archipelago. The islands comprise a mix of unvegetated sand cays $(\sim 70)$ and vegetated islands $(\sim 50)$. The vegetated cays, which are the focus of this discussion, occur in three discrete zones, the outer shelf and barrier rim (23 islands), mid shelf ( 9 islands) and the nearshore (17 islands) (Figure 2, Table 1). A number of observations arise from inspection of the spatial distribution of vegetated islands in the archipelago. (i) There are few islands (8) located on the outer barrier reef rim. Those islands that do occur on the rim are principally located in the north. The paucity of islands suggests a hydrodynamic energy control where sediment may be transported across reefs and flushed into the adjacent lagoon (Mandlier and Kench, 2012). (ii) Remaining outer shelf islands are located on individual smaller reef patches within the lagoon. Notably, there are still numerous platforms without islands on the outer shelf. (iii) Mid-shelf islands are located on patch reefs that emerge from a broad carbonate platform (5-10 $\mathrm{m}$ depth) that occupies the central sector of the lagoon. (iv) Nearshore islands are found on reefs emerging from a shallow carbonate platform ( $\sim 5 \mathrm{~m}$ depth) that adjoins, or likely underlies the coastal plain. (v) Spatial differences in island size exist across the reef system (Table 1). The mean area of outer barrier rim islands is 11.3 ha (Table 1), whereas remaining outer shelf and mid shelf islands have mean areas of 4.2 and 4.4 ha, respectively. Nearshore islands have a mean size of 11.1 ha but include the two largest islands Pulau Sabanko (36.6 ha) and Pulau Sagara (32.4 ha, Table 1, Figure 2). Observed differences in island size may be partly governed by the availability of reef platform area for accumulation, balanced against the relative energy and sediment grade properties characteristic of individual reefs.

Few studies have examined the detailed morphology and sediment characteristics of islands in the archipelago. As noted earlier Umbgrove (1929) generated the first 

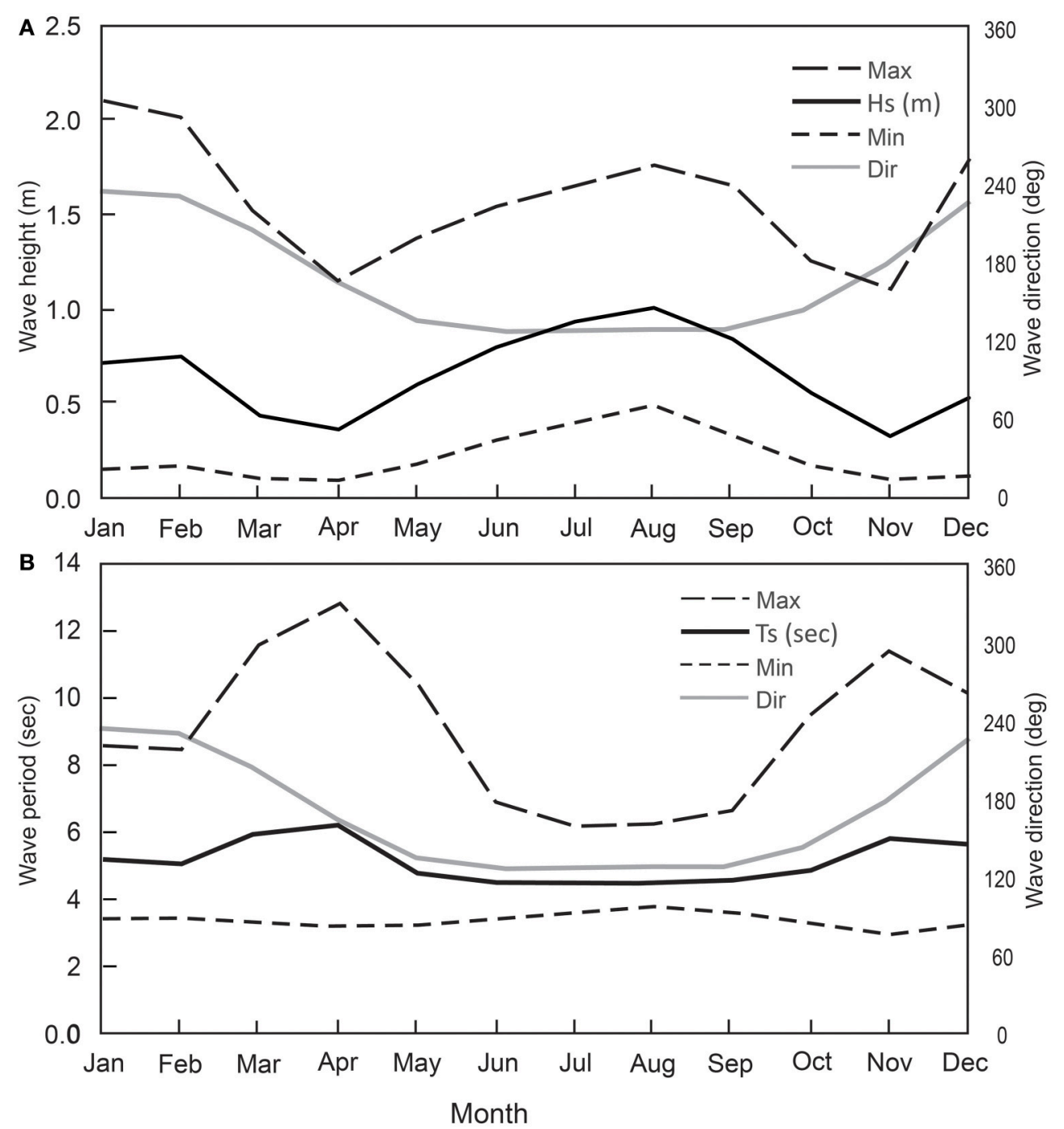

FIGURE 4 | Monthly average of hourly wind and wave data between 1980 and 2010 west of Spermonde. (A) Summary wave height statistics; (B) Wave period statistics. Wave direction shown as gray line in both panels. Source: WWIII records spanning 30 years (1980-2010).

planform maps of a number of islands, which forms an excellent basis for comparison of past change. Mann (2015) undertook topographic surveys on a limited number of islands, which demonstrates the low-lying nature of the islands $(<1.5 \mathrm{~m}$ above $\mathrm{msl})$ and characteristic basin morphology of island surfaces (see also Janßen et al., 2017). To date no rigorous comparison of planform changes of the islands of Spermonde has been undertaken since the early mapping of Umbgrove.

Whereas initial analyses of the sediments of a small sample of islands in the archipelago focused on specific sedimentary constituents and their pathways (Wizemann et al., 2015), a recent facies study found they are dominated by mediumcoarse grained sands that are poorly sorted (Janßen et al., 2017). The study also indicated spatial gradients in the texture and composition of sediments comprising islands. Notably, outer shelf reef islands were composed of coarser sediments (sandy gravels) than nearshore islands (gravelly sands). Furthermore, outer reef islands were composed of a mix of coralline algae and coral constituents (collectively 70-80\%) whereas surficial sediments on the nearshore island were dominated by coralline algae $(\sim 60 \%)$. In all islands secondary constituents such as molluscs, foraminifera and Halimeda contributed less than $12 \%$ each to the sediments. These results are consistent with studies reported elsewhere, which show islands are dominated by coral/coralline algae facies in the Pacific and Indian Ocean (Woodroffe et al., 1999; Kench et al., 2012, 2014a). Janßen et al. (2017) also highlight compositional shifts in sediments, which provides insights into ecological transitions in mid-shelf reefs that have implications for sediment production regimes. In particular, the dominance of coralline algae in surface sediments may reflect a change from the major phase of island building where predominantly coral constituents have formed the core of islands. 
TABLE 1 | Summary of location and area of major vegetated islands of the Spermonde Archipelago.

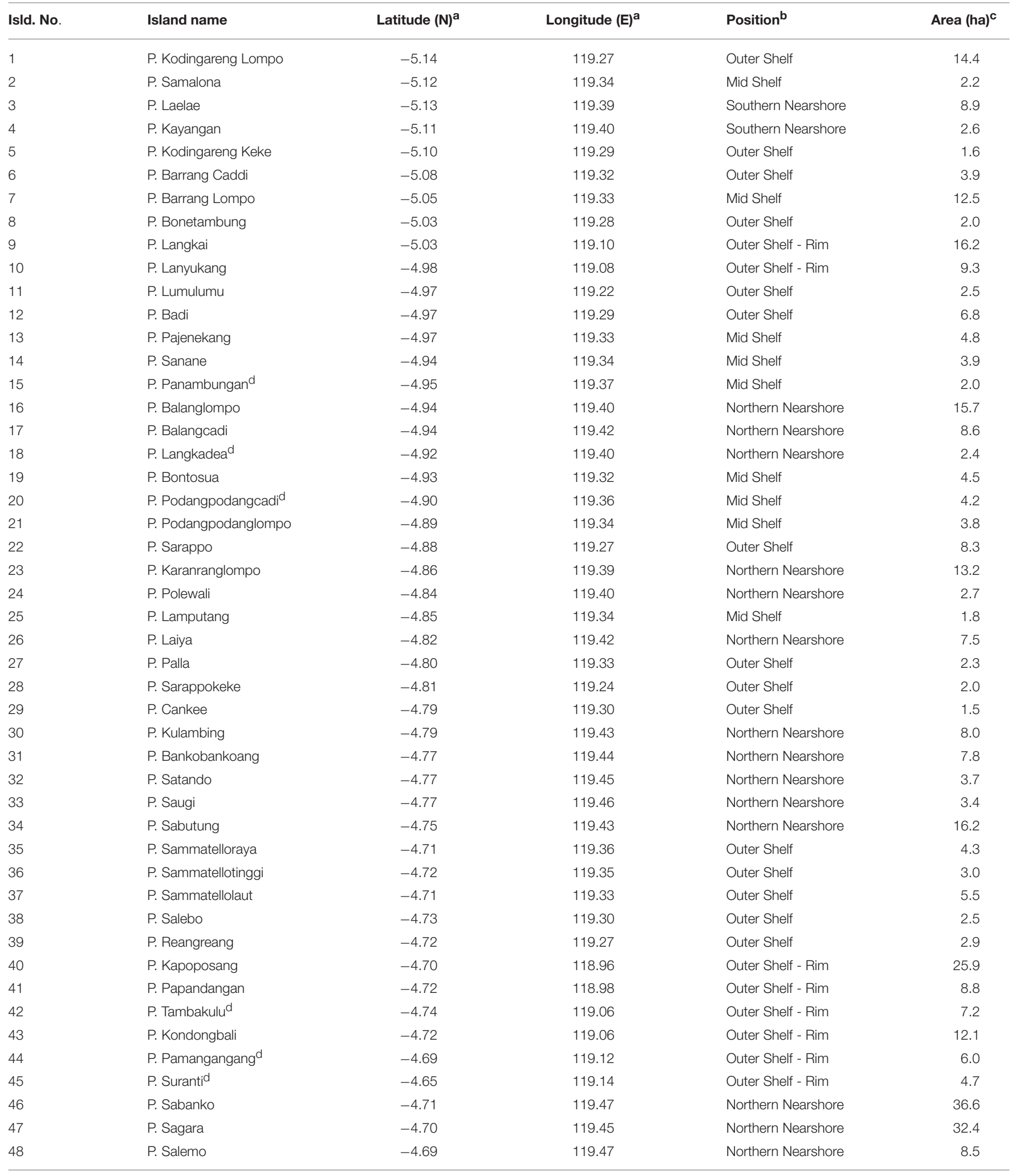

For island locations refer to island numbers as indicated in Figure 2.

${ }^{a}$ Decimal degrees, ${ }^{b}$ Following Renema (2002) and authors classification, ${ }^{c}$ Approximations from medium-resolution satellite images (except for denoted islands) and own observations, ${ }^{d}$ Area surveyed by the authors in Oct/Nov 2012. 


\section{CONTROLS ON REEF ISLAND EVOLUTION AND MORPHOLOGICAL DYNAMICS}

From a physical landform perspective reef island development and ongoing morphological change is governed by a series of critical boundary conditions (Kench, 2013). First, sea level change and its control on reef growth and platform development, which is considered a primary control on the future stability of islands. Second, available accommodation space, defined as the volume for sediment deposition, and which is governed by substrate gradient, elevation and sea level (Cowell and Thom, 1994). Storm wave runup processes control the maximum extent of vertical land building, which also have a relative sea level control. The lower limit of accommodation space is determined by reef platform elevation and lagoon depth. Third, sediment supply which is governed by carbonate budget dynamics and sediment generation processes (Perry et al., 2013). Fourth, the hydrodynamic regime characterized by wind, wave and current processes as well as the frequency of extreme events that transport and deposit sediments on reef surfaces. These factors are examined in the following sections and implications for islands of the Spermonde are discussed.

\section{The Role of Sea Level and Reef Development in Island Formation}

The influence of sea level on reef development is widely perceived as the most important control on the evolution and future stability of reef islands. Initial theories embraced a sequential model of island evolution whereby sea-level stabilization, completion of vertical reef development and reef flat formation at sea level were precursors for the evolution of islands. Supporting evidence of this linear model is found in examples from the midPacific and Indian Oceans, where for the past 6,000 years sea level has been at or slightly higher than present (Woodroffe et al., 1999; Woodroffe and Morrison, 2001; Kench et al., 2012, 2014a).

However, disparities in late Holocene sea-level dynamics and reef growth responses (timing and magnitude of change) between reef regions have provided differing boundary conditions and temporal constraints for the onset and accumulation of reef islands. Recent studies suggest that island initiation and development is more complex. Islands have been shown to form under both rising and falling sea-level conditions, and across substrates of varied elevation and composition (Woodroffe et al., 1999; Kench et al., 2005). Notably, these studies also highlight that island formation is dependent on the relationship between sea level and reef platform development and not just one of these variables. From the limited number of studies that have reconstructed island formation in relation to both sealevel change and reef growth, three models can be proposed for reef island formation, which differ in the elevation and type of substrate over which they accumulate and in the sea-level history coincident with island formation. First, islands can form on emergent conglomerate platforms, or reef flats, exposed by midlate Holocene sea-level fall. This model is supported by evidence of islands perched on raised conglomerate in the Indian Ocean (Woodroffe et al., 1999) and emergent reefs at other locations in the Pacific (Kench et al., 2012, 2014b). Second, islands can form across sea-level constrained reef flats, as has been demonstrated in Tuvalu (McLean and Hosking, 1991; Kench et al., 2014a) and Fiji (McKoy et al., 2010). The third model allows reef island formation over submerged reefs and sedimentary deposits as sea-level rise slowed toward the mid-Holocene highstand as demonstrated in the Maldives (Kench et al., 2005, 2009a).

Recently published evidence of the Holocene sea-level history in the Spermonde Archipelago (Mann et al., 2016a) provides insights on the likely evolutionary sequence of islands. In particular, Mann et al. (2016a) present evidence from fossil microatolls that the sea first reached its present level prior to $\sim 6,500-6,000$ years before present (yBP, Figure 5). Microatoll evidence also reveals a higher sea level of $\sim 0.5 \mathrm{~m} 5,500 \mathrm{yBP}$ before falling to its current position 4,000 years ago after which it has likely remained relatively stable. This broad pattern of sea level change and the evidence used to construct it also provides insights into the Holocene reef growth in the Spermonde. In particular, emergent microatolls dated at $\sim 5,500 \mathrm{yBP}$, on reef flats suggests reefs either kept up with Holocene sea-level rise, or were able to catch up to sea level during the highstand. Both possible trajectories suggest rapid reef accretion in the early to mid-Holocene soon after the shelf was flooded. Furthermore, this evidence suggests reef platform surfaces have been at or near current sea level for the past 4,000 years providing a broad time window for island accumulation. Consequently, given sufficient supplies of sediment it is possible that some islands in the Spermonde may have begun accumulating 6-5,000 years ago at higher sea level, as shown in the Cocos (Keeling) Islands

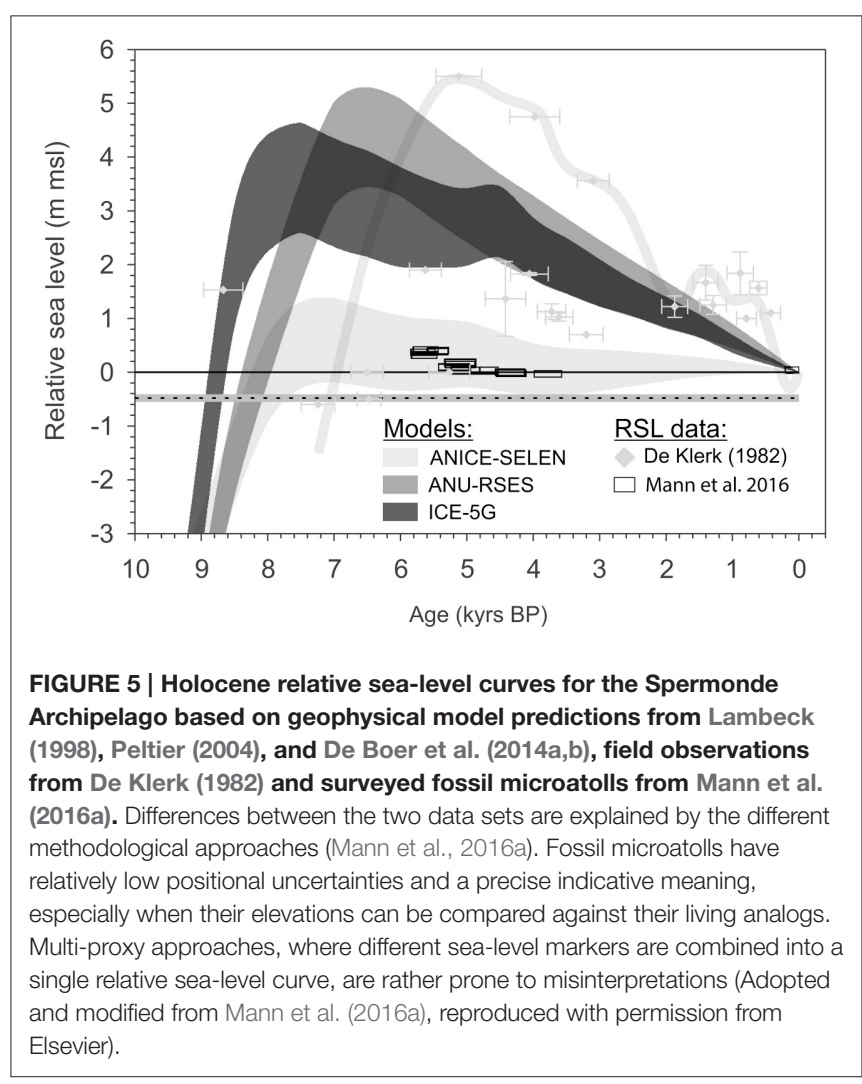


(Woodroffe et al., 1999); Jabat Island, Marshall Islands (Kench et al., 2014b) and Bewick Island, Great Barrier Reef (Kench et al., 2012). Such islands would have become emergent as sea level fell suggesting they would be higher in elevation than islands formed at lower sea levels and would be currently perched above the process regime under which they were formed. In addition islands may have continued to form as sea level fell, across emergent platforms 5,500-4,500 years ago and subsequent to the sea level still stand.

In the absence of detailed chronostratigraphic studies it is not possible to refine the timing of the onset and temporal window of island building. However, it is feasible that islands have continued to accumulate during each of the sea-level phases as a consequence of differential reef growth and platform development between outer, mid and nearshore reef sites. For example, aerial imagery from across the shelf suggests differing reef geomorphic structures and basements of islands (Figure 6). At a number of outer and mid-shelf sites, islands appear to be deposited directly on top of reef flat surfaces (Figures 6A-F). However, the nature of reef development has not been as planar reef surfaces at all locations, but also as reticulate reef networks that can be found in the nearshore (Figures 6G-I). In addition to sea-level changes, reef platform geomorphology influences the timing of island formation. For example, in settings with a higher elevation reef rim and shallow lagoons, infill of lagoons would be required as a precursor to island formation which may have delayed the timing of island formation on some reefs. On larger reef platforms therefore, the onset of island formation is likely to have been delayed as large lagoon volumes required infill prior to island development, as has also been found in Maldivian faros (Perry et al., 2013). Resolving potential differences in reef growth and onset of island accumulation would provide a more robust basis to understand island formation dynamics in the archipelago.

\section{The Importance of Sediment Supply for Island Building}

Island formation necessitates the generation and transfer of carbonate sediments to fill the accommodation space between the platform surface and maximum wave runup limit. It is widely perceived that the reef "carbonate factory" yields a quasicontinual supply of sediment to build or maintain landforms. However, existing studies indicate that the composition and supply of detrital sediment available for island formation can vary temporally as a consequence of changes in reef growth/reef ecology (Yamano et al., 2000; Woodroffe, 2008; Perry et al., 2011) and these in turn influence the pattern of island accumulation.

While numerous studies have shown that islands first appeared in the middle Holocene $(\sim 5,000$ years ago), which could also be the case in the Spermonde based on the sea level and reef development patterns, evidence suggests that the subsequent accumulation history may follow different patterns controlled by sediment availability (Kench, 2013). For example, Warraber Island in the Torres Strait formed continuously over the past $3,000-5,000$ years in response to a sustained supply of sediment (Woodroffe et al., 2007). However, in other settings formation appears to have been more episodic. Kench et al. (2005) shows Maldivian reef islands formed in a constrained 1,500 year period in the mid-Holocene and building slowed dramatically 3,500 years ago. Additionally, in storm-dominated environments island formation has been characterized by periodic deposition of storm generated rubble (Maragos et al., 1973; Bayliss-Smith, 1988; Hayne and Chappell, 2001).

Differences in sediment accumulation patterns between islands can be partly explained through temporal transitions/variations in sediment supply during island formation and recognition that the relationship between reef production and sediment generation is not linear (Perry et al., 2011). Changes in sediment generation are therefore, likely to reflect alterations in the delicate balance between reef growth and productivity through time. For example, triggers for island formation in the mid-Holocene appear to be coincident with reefs either attaining sea level or reaching wave base and releasing a pulse of excess carbonate sediment (Kench, 2013). Sediment pulses may also have resulted from reef flat emergence. Indeed, sea level driven changes in the ecology of reef flats would have altered the dominant constituents available for island formation from sediments derived from primary producers (e.g., frame builders such as coral) to secondary benthic producers (e.g., foraminifera, calcareous green algae). For example, Green Island, Great Barrier Reef, is considered to have formed following a transition in reef flat ecology to foraminifera dominance following sea-level stabilization (Yamano et al., 2000). Of note, the sedimentological evidence from the Spermonde also suggests that the core sediment of mid-shelf reef islands was dominated by coral, but that the surface beach materials are now dominated by coralline algae (Janßen et al., 2017). Such a transition suggests changes in the dominant carbonate producers on the surrounding reef platforms.

\section{Process Controls on Island Development}

While sea level, reef platform development and sediment availability are essential components of island formation it is the hydrodynamic process regime (waves and currents) that interact with reef structures to entrain, transport and deposit sediments at nodal locations on reef surfaces to construct islands (Stoddart and Steers, 1977; Gourlay, 1988; Kench, 2013). The importance of wave-reef interactions for island construction and change are expressed in two ways. First, reefs act as a filter to wave energy thus modulating the available energy to perform geomorphic work. Second, the configuration of reef platforms refracts and diffracts wave energy which can influence the location that islands occupy on reef surfaces and their ultimate planform shape (Gourlay, 2011; Mandlier and Kench, 2012).

The physical interaction of waves with coral reefs causes incident energy to transform, break and release energy. Consequently, through the breaking process, reefs are able to reduce incident energy by up to $90 \%$ (Roberts et al., 1977; Lee and Black, 1978; Roberts and Suhayda, 1983). However, despite large reductions in wave energy at the reef edge, remnant energy propagates across reef surfaces and is available to activate geomorphic processes and influence island development. The propagation of wave energy onto reef platforms is controlled 


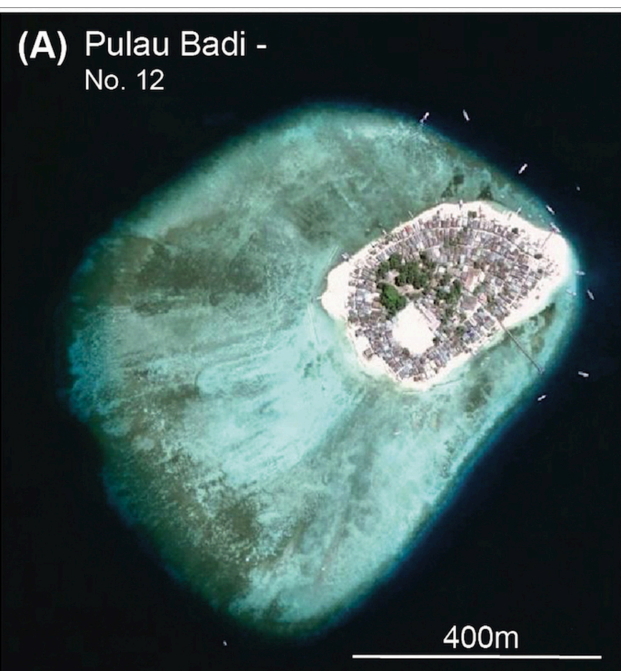

(B) Pulau Sarappo th No. 22

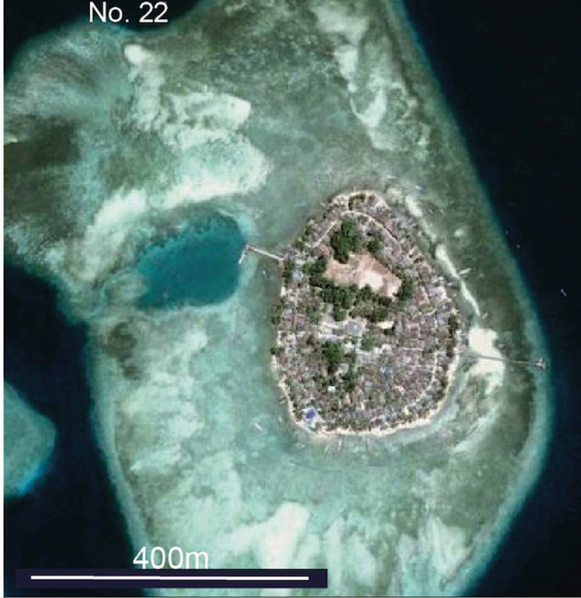

(C) Pulau Salebo No. 38

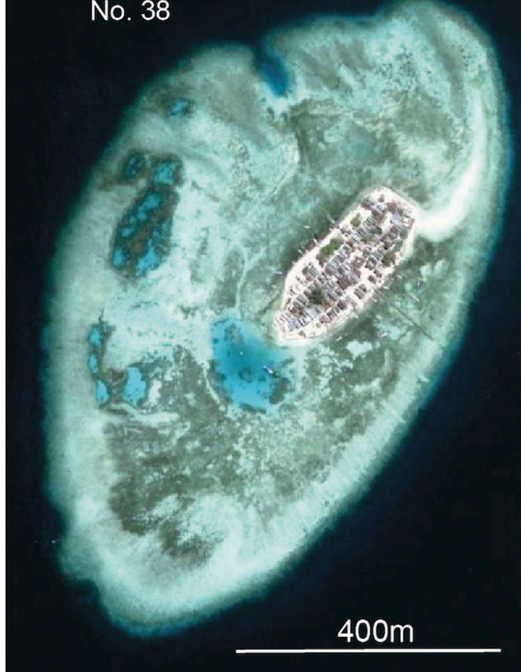

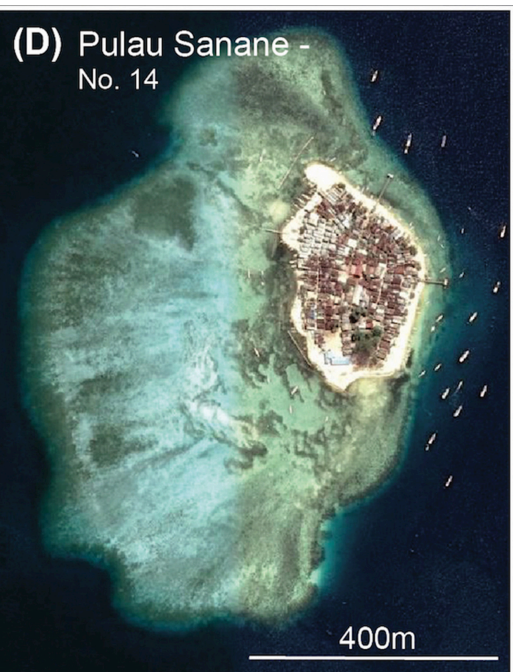

(E) Pulau Panambungan No. 15

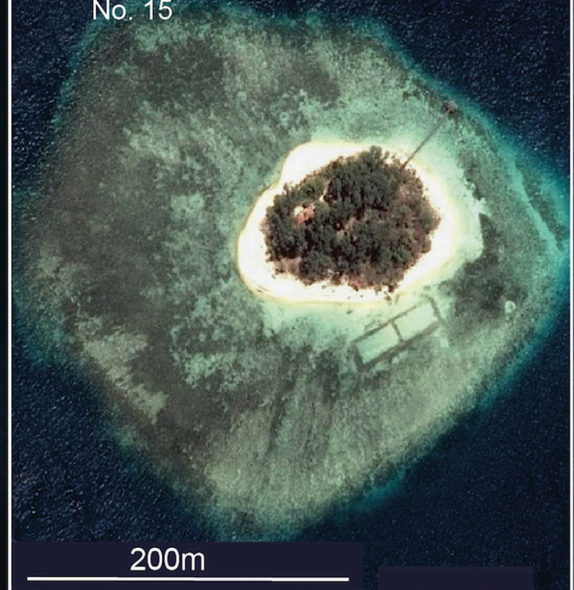

(F) Pulau Lamputang No. 25

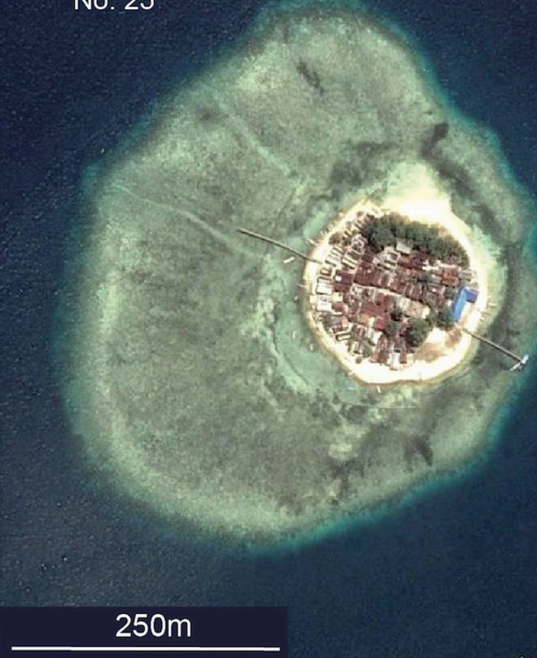

(G) Pulau Balanglompo No. 16

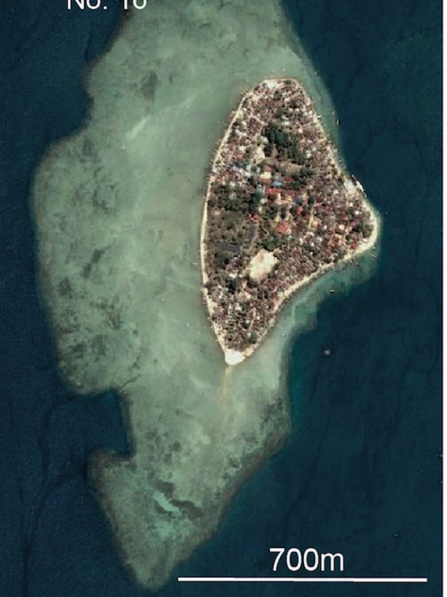

(H) Pulau Balangcadi No. 17

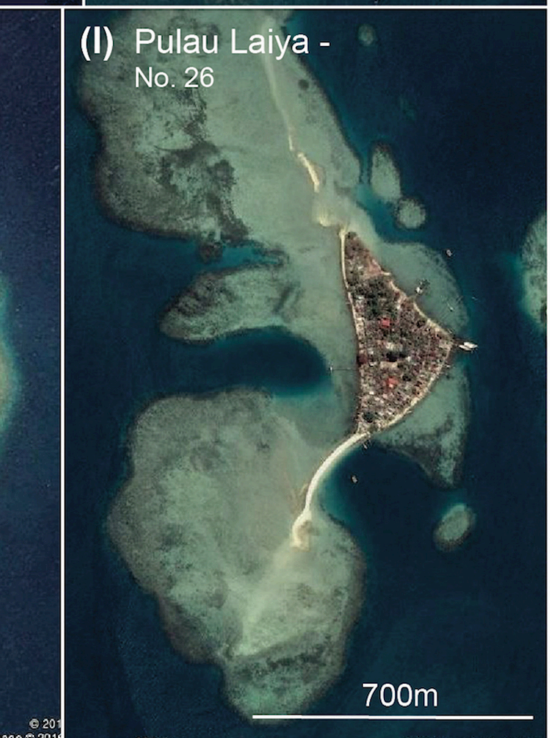

FIGURE 6 | Examples of reef island planform shape and location on reef surfaces on the outer rim (A-C) , mid-shelf (D-F), and inner shelf (G-I). Note number of islands with anthropogenic modification. Location of islands shown in Figure $\mathbf{2}$ and size of islands presented in Table 1. Numbers below island names refer to Table 1 and Figure 2 (Satellite images from Google ${ }^{\mathrm{TM}},{ }^{\odot} 2017$ DigitalGlobe). 

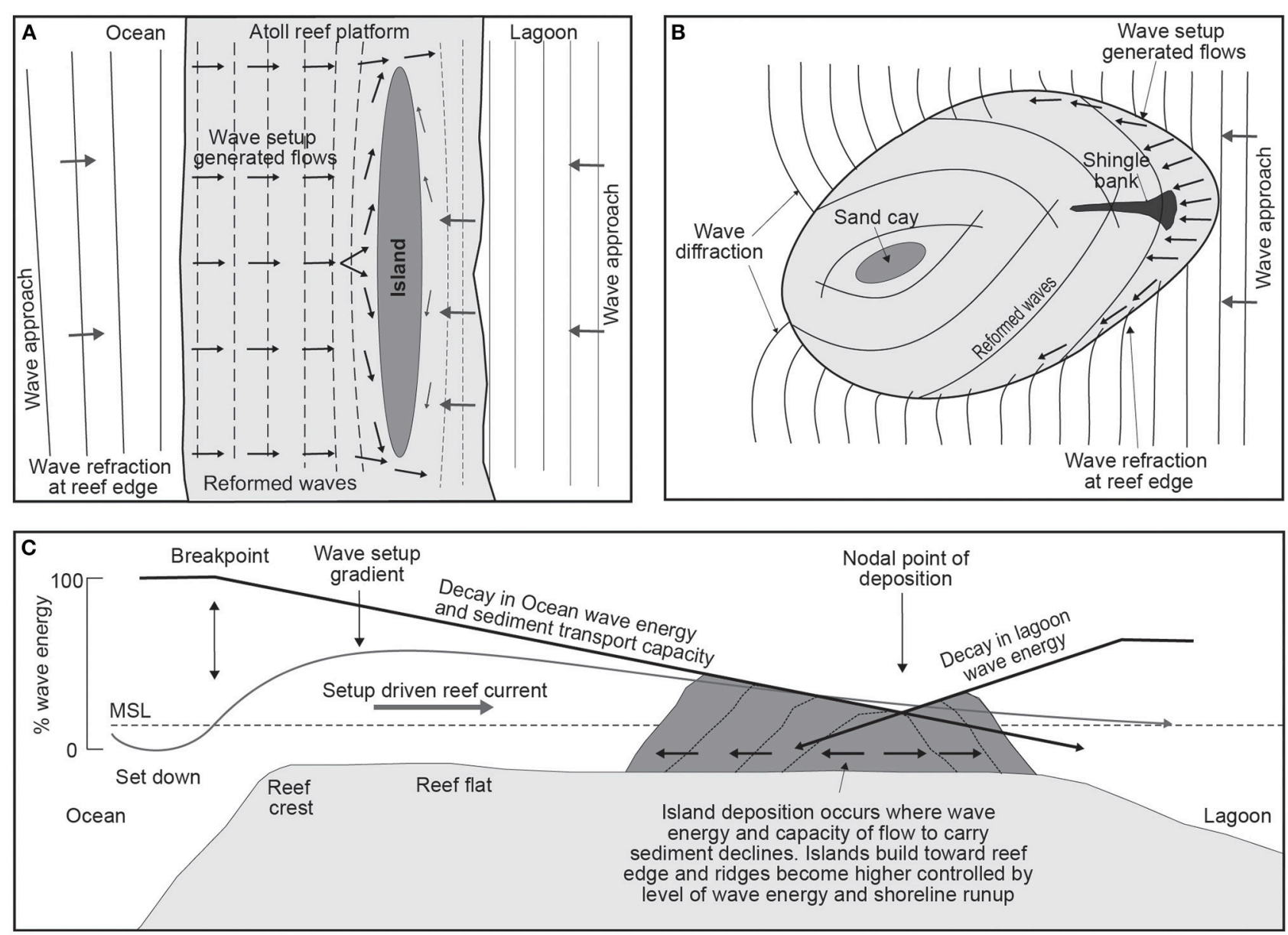

FIGURE 7 | Conceptual models of wave interaction with reef platforms, resultant current gradients and controls on island formation. (A) Wave interaction with a linear atoll reef rim. (B) Isolated reef platforms where wave energy can refract around the platform. (C) Idealized ocean-to-lagoon cross-section showing the decay in wave energy and generation of wave setup driven currents across reef flats. The decay in wave energy and current energy reduces the capacity to transport sediment, providing an envelope for the accumulation of sediments at nodal points on reefs (islands). As islands build toward reef the edge they accrete vertically in response to increased wave energy and runup processes.

by tidal stage and is at a maximum at higher water (Roberts et al., 1977; Brander et al., 2004). Reef width and water depth across reef surfaces have been found to be important controls on the incidence of wave energy at island shorelines (Brander et al., 2004; Lowe et al., 2005; Kench and Brander, 2006a; Kench et al., 2009b,c). In general, wave energy on reefs and the ability to perform geomorphic work at island shorelines increases with relative water depth (h) and as the reef width decreases as captured in the "reef energy window index" (Kench and Brander, 2006a). Consequently, as reef width increases wave energy diminishes through additional frictional dissipation. Ultimately, the cross-reef energy reduction typical of most reef platform surfaces constrains the amount of time that the sediment transport system is activated.

As both wave and current energy generally reduces in magnitude from reef edge across reef platforms, the intersection of energy gradients across small platforms promotes deceleration of currents, creating a nodal point for sediment accumulation (Figure 7). On linear reef rims, as it is the case for many atolls but also the barrier edge in Spermonde, wave energy gradients are unidirectional from ocean-side reef to lagoon (Figure 7A), often resulting in linear island orientation (Figure 7A and also see islands 40, 42, 44, and 45 on Figure 2). However, on circular or complex shaped reefs wave refraction and diffraction patterns generate a more complicated set of energy gradients that interact on the reef surface to produce depositional centers (Figure 7B; Mandlier and Kench, 2012).

Island building, therefore, is dependent upon the gross energy incident at reefs, the relative filtering effect of coral reefs, which varies spatially depending on reef elevation and the configuration of reef structures that influence the direction of energy gradients. Furthermore, it is the interaction of this reef top energy regime, when combined with the grade of the available sediment reservoir, which determines the location, morphology and sedimentary character of reef islands. In higher energy settings the across reef current gradient is steeper than in moderate to low energy environments. Consequently, higher energy settings are capable of transporting a wider range of sediment sizes and/or activate transport for longer duration than low energy environments (Kench, 2013). In linear reef 
settings the cross-reef deceleration of currents combined with the competency of flow to transport sediment will determine the location of deposition. In such settings islands tend to prograde toward the reef edge. On circular platforms the nodal location of wave energy interference provides the depocenter for sediment accumulation. In these settings islands may prograde around their entire circumference. Furthermore, as islands prograde across reef platform surfaces toward the reef edge, shorelines are gradually moved into incrementally higher energy settings. Consequently, shoreline runup processes are more active which allows island margins to build higher with respect to sea level (Figure 7C). The result of this style of deposition is a characteristic basin shaped morphology to island surfaces as profiles of a number of islands do show. Furthermore, crossshelf differences in energy should also be expressed in differences in island topography. In particular, more energetic wave runup processes at exposed outer reef sites should promote higher island margins than at lower energy sites, as also shown by Kench et al. (2006a) in the Maldives.

The relative balance of energy, reef configuration and sediment caliber provides a useful framework to consider the distribution of islands in the Spermonde. Although undocumented it is assumed there is a general reduction in wave energy from the outer shelf rim to nearshore reef systems. Of note, there are few islands on the western barrier (Figure 2) which may reflect the fact that incident energy is effective at transport sand-size materials across the reef surface and that sediments may be flushed across the reef into the lagoon and are unable to achieve an equilibrium position on the barrier reef surface. In general, islands become more common in the mid shelf and nearshore, which is likely to reflect a finer balance between energy and sediments that do achieve a depositional node on the reef surface. Notably, islands on circular platforms largely mirror the reef configuration but tend to be positioned toward the landward side of the reef surface. A number of nearshore islands have been deposited at the landward side of individual reticulate reef platforms and in some instances appear to have prograded onto and across the landward fore-reef slope (Figures 6G-I).

\section{MORPHODYNAMIC BEHAVIOR OF REEF ISLANDS}

Since the earliest detailed observations of reef islands there has been abundant evidence that reef islands are dynamic landforms (Umbgrove, 1929; Verstappen, 1954; Stoddart, 1965; Hopley, 1978) that are able to adjust their position, shape and size on reef surfaces. In recent decades the international concern over island stability in the context of global change has heightened the interest in resolving the precise drivers of island change and the possible styles of island adjustment in order to better resolve future island dynamics. The morphodynamics of reef islands are manifest via continual physical adjustments to alterations in the process regime that are driven by changes in climate, incident waves, sea level and sediment availability. These process driven changes occur at a range of temporal scales.

\section{Extreme Events}

Short-period extreme events such as tropical hurricanes, cyclones and storms have been well recognized for their ability to drive near-instantaneous geomorphic change on reef islands as a consequence of super-elevated water levels and extreme wave heights (Blumenstock, 1958; Blumenstock et al., 1961; Stoddart, 1971; Stoddart and Steers, 1977; Woodley, 1980; Woodley et al., 1981; Bayliss-Smith, 1988; Harmelin-Vivien, 1994; Williams et al., 2010). However, less well-documented are the impacts of tsunami (Kench et al., 2006b, 2008) and longer period swell events (Smithers and Hoeke, 2014) in forcing changes to islands at timescales of seconds to days.

Collectively, extreme events can promote both erosion and accretion responses on reef islands. Bayliss-Smith (1988) proposed the earliest morphodynamic model for islands based on their disparate behavior to extreme events. He suggested the mode of morphological change depended on the sedimentary composition of islands and storm frequency and intensity (Figure 8). Sand dominated islands, located in environments with low storm frequency, or sheltered from storm impacts, are susceptible to erosion during extreme wave events. Such extensive erosion was documented on the sand cays on the Belize barrier reef in response to Hurricane Hattie (Stoddart, 1963). In contrast, in storm-dominated and exposed settings, islands are commonly composed of coarse rubble and their morphological response to storms can be different to sand cays. Storm events can generate large volumes of material, by mechanically removing living coral communities and depositing this material on reef flats and on islands. Such storm aggradation was observed by Bayliss-Smith (1988) in islands in Ontong Java and by Ford and Kench (2016) in the Marshall Islands. Furthermore, Maragos et al. (1973) documented the deposition of $1.4 \times 10^{6} \mathrm{~m}^{3}$ of storm rubble on the windward reef platform of Funafuti atoll, Tuvalu as

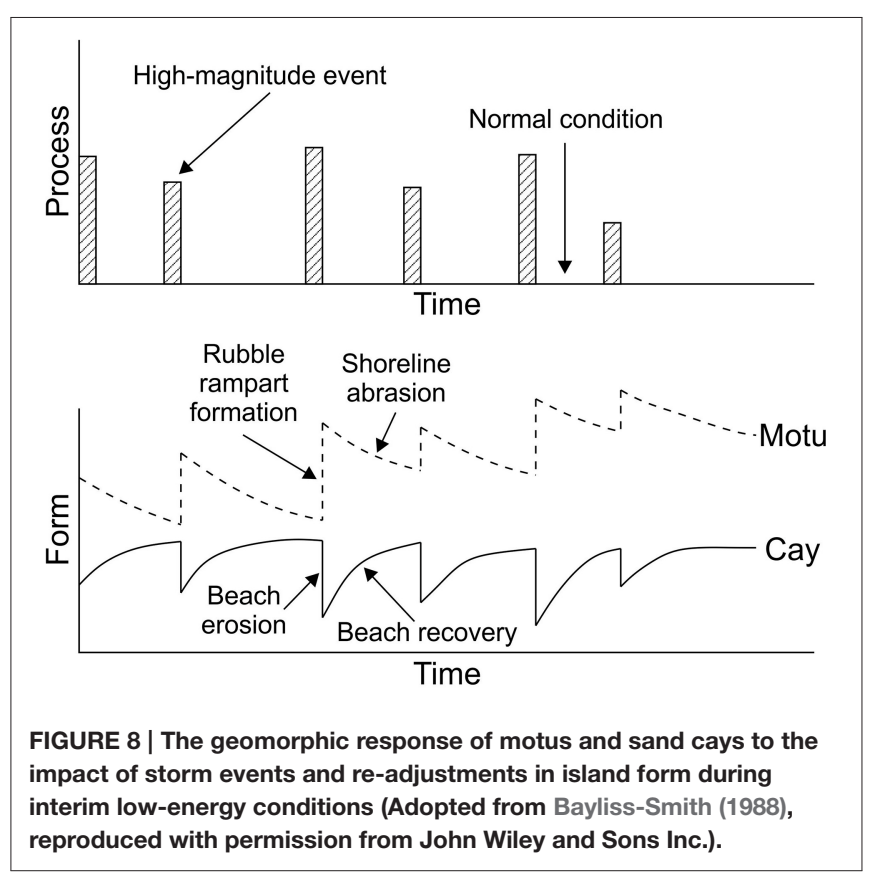


a consequence of Hurricane Bebe in 1972. Subsequent reworking of this sediment onto island shorelines has expanded island area up to $10 \%$ (Kench et al., 2015).

In recent years the effects of tsunamis and long-period swell waves on reef islands have been analyzed in more detail. Kench et al. (2006b, 2008) were the first to provide direct and quantitative observations of the geomorphic impacts of tsunami on islands in the Maldives as a consequence of the Sumatran tsunami (December, 2004). Based on surveys and the sedimentary analyses of the pre- and post-tsunami island surface, Kench et al. (2006b, 2008) showed that tsunami waves washed over significant parts of the study islands in South Maalhosmadulu Atoll. The impact, which coincided with the northeast monsoon, resulted in a temporary geomorphic disequilibrium where the depletion of beach sediments on the exposed shoreline sections led to the continued retreat of island scarps in its aftermath. Indeed the tsunami event is credited with performing the geomorphic work normally accomplished across the entire northeast monsoon season. In addition washover sedimentation was able to contribute to vertical island building across significant portions of island surfaces. Nevertheless, the observed geomorphic changes on the analyzed islands indicate that reef islands are robust against the impact of high-energy tsunami waves. A similar set of effects that include shoreline erosion, deposition and washover sedimentation have been described for Takú Atoll in the Pacific following long period swell events (Smithers and Hoeke, 2014). Planform reef island recovery after this swell event was characterized by negative feedback processes, typical for open-geomorphic process-response systems (Mann and Westphal, 2016; Mann et al., 2016b).

There have been no detailed accounts of the impact of extreme events on islands in the Spermonde Archipelago. The latitudinal location suggests the islands do not experience extreme cyclonic events. While the sedimentary composition of islands (coarse to medium sands) is consistent with a non-cyclone setting, storm events are still likely to promote changes of island shorelines. However, such changes are postulated to follow the sand cay mode of Bayliss-Smith (1988) with shoreline erosion followed be a period of recovery rather than storm generated expansion of islands through the generation of large rubble sheets. While extreme climatic events may not be prominent in the archipelago, it is situated in a broader tectonically active region where the generation of tsunami has been regular over the middle to late Holocene and therefore could drive periodic transitions in island morphology.

\section{Seasonal Timescales}

Predictable shifts in monsoon wind directions on a seasonal timescale affect the short-term geomorphology of reef islands as wind-waves are able to entrain reefal and beach sediment and transport it to depositional nodes around the island footprint (Stoddart and Steers, 1977; Gourlay, 1988; Brander et al., 2004; Kench et al., 2006a; Kench and Brander, 2006b). A good understanding of monsoonally controlled changes in beach systems of reef islands is important for adequate coastal management decisions. However, in recent years only a few studies have analyzed in detail the geomorphic response of reef island shorelines to the effects of seasonal fluctuations in wind, waves and currents. Kench and Brander (2006a) examined the seasonal adjustment of shorelines around eight islands in South Maalhosmadulu Atoll, Maldives. Their results showed that reef islands experienced considerable planform beach adjustments between seasons $( \pm 53 \mathrm{~m}$ ), with beach sediments driven by energy vectors from the windward to leeward sides of islands. Notably, the study found that: (i) while seasonal fluxes of sediment were large they were balanced at the annual scale; (ii) beach reorganization occurred in the alongshore direction; (iii) patterns of beach change were predictable for each island; and (iv) the pattern of beach adjustment varied between islands of different shape. Results were synthesized into an island oscillation index which can be used to establish the sensitivity of shorelines to shifts in climate regime. These results were later confirmed by additional studies on seasonal wave characteristics and monsoonally influenced sediment circulation around reef islands in the same area (Kench et al., 2009a,b,c). Analyses showed circular islands, of which there are numerous in the Spermonde Archipelago, were most sensitive to changes in incident wave processes.

More recently, Mann and Westphal (2014) examined the opportunity to detect seasonal changes in the beach extent on interannual high-resolution remote sensing data from Takú Atoll. The recognition of such monsoonally influenced beach sections allows for the calculation of long-term changes in planform beach morphology of reef islands despite the common temporal gap in available remote sensing data.

It is evident that the predominantly sand islands of Spermonde are also subject to large-scale fluctuations in beach volume around island shorelines, which would appear to be forced by changes in monsoon wind fields and wave patterns (Figure 9). A quantitative analysis of such changes and the process drivers, which is currently lacking, would provide a more robust basis for coastal management decision making.

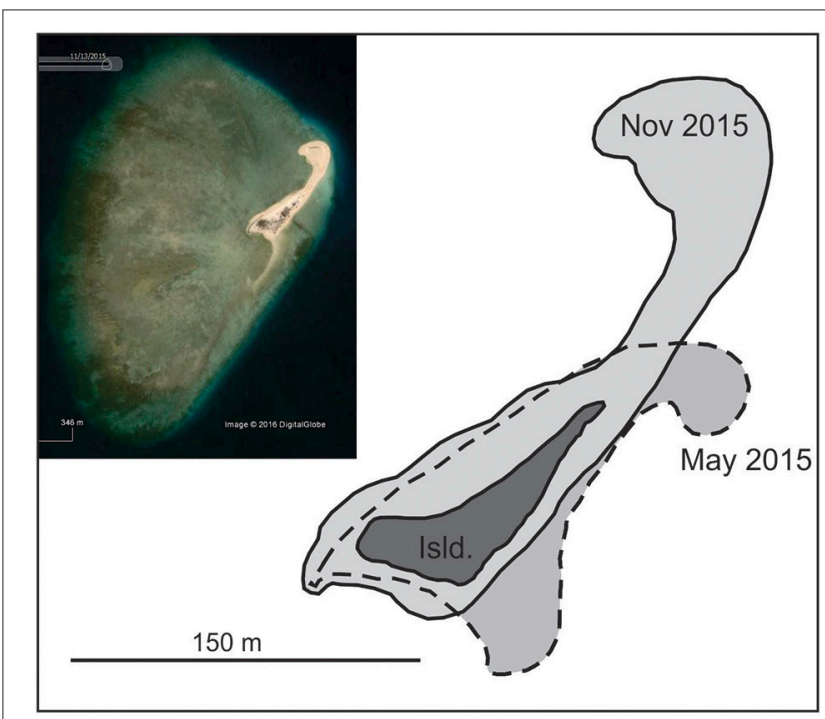

FIGURE 9 | Example of seasonal shifts in beach position due to changes in monsoon wind direction around Pulau Kodingareng Keke (Island 5 in Figure 2 and Table 1), a small vegetated sand cay on the outer shelf (Satellite image from Google ${ }^{\mathrm{TM}},{ }^{\odot} 2017$ DigitalGlobe). 


\section{Multidecadal-Centennial Timescales}

At longer timescales reef islands respond to long-term shifts in wind and wave climates, sea-level change and sediment supply. However, attributing the role of each factor in island change has yet to be definitively resolved. At interannual to decadal timescales variations in wind conditions (e.g., El-Nino Southern Oscillation variations) and their influence on physical processes on reef surfaces (e.g., wave energy and sediment flux) have been shown to govern the morphological and planform changes (migration) of islands (Verstappen, 1954; Flood, 1986; Dawson and Smithers, 2010).

Webb and Kench (2010) presented detailed alterations in the planform configuration of atoll islands in the central Pacific over four decades, a period in which sea level had risen 2 $\mathrm{mm} / \mathrm{yr}$. Their detailed observations showed that all islands had undergone morphological change although the magnitude and style of change differed between islands. Forty three percent of islands increased in size while a further $42 \%$ of islands showed little net change over the period of analysis. Only 15\% of islands had decreased in area. Webb and Kench (2010) also showed that net changes across four decades masked much larger gross morphological adjustments in islands. In particular, ocean shoreline erosion and lateral extension of islands was common. In general, differences in erosion and accretion around island shorelines resulted in migration of islands on reef platforms toward the lagoon. Such findings are consistent with Stoddart (1963) who attributed lagoon migration of islands in the Belize Barrier Reef to rising sea level. However, a primary conclusion from Webb and Kench (2010) was that sea-level rise had not caused widespread erosion of reef islands. With the exception of one study (Albert et al., 2016), similar conclusions have been drawn by subsequent studies that evaluated decadal-scale shoreline changes on reef islands based on the interpretation of remote sensing data (Ford, 2011, 2013; Rankey, 2011; Yates et al., 2013; Ford and Kench, 2014, 2016; Mann and Westphal, 2014, 2016; Mann, 2015; McLean and Kench, 2015; Mann et al., 2016b; Testut et al., 2016; Duvat and Pillet, 2017). Notably, Kench et al. (2015) examined changes in islands of Funafuti atoll over more than a century, and also found a lack of consistency in island response, with the majority increasing in land area. Ultimately, the weight of studies indicate islands are robust geological entities that are likely to persist across the next century, but will continue to undergo morphological change. It would seem that an array of short-term environmental processes such as storms, wind variability, sediment supply and anthropogenic impacts all interact to influence island morphological adjustment across a range of temporal scales and make it difficult to isolate the impact of sea level as an individual driver of island change (McLean and Kench, 2015).

\section{PERSPECTIVES FOR RESEARCH IN THE SPERMONDE ARCHIPELAGO}

Over the past three decades there have been considerable advances in understanding the geological evolution and environmental controls on development and ongoing change of islands in mid-ocean atoll settings such as the Maldives, Kiribati and Marshall Islands. In contrast there has been a paucity of scientific investigations of islands in the Spermonde Archipelago (or wider Indonesian archipelago). At the interface between the Pacific and Indian Oceans and amid the coral triangle, the Spermonde Archipelago is in a unique tectonic and oceanographic setting. Furthermore, the inferred acrossshelf energy gradient provides an excellent laboratory to examine differences in island building processes. From a scientific perspective there are likely to be significant new insights to be gained from detailed investigations of islands in the archipelago. Indeed it is important to test and verify current models of island formation and dynamics and it is conceivable these models will be further extended from additional research effort. From a practical coastal management perspective additional research is necessary to better predict the future transformations in islands and support the ongoing management of islands. Consequently, we recommend four research priorities.

1. In the context of understanding island evolution and ongoing stability it is essential to resolve questions concerning the timing of island development, whether, islands formed synchronously and whether islands continue to have active sediment linkages between the reef platform and island shorelines. To date, no data has been published on the age of sediments comprising islands in the Spermonde Archipelago or attempted to construct a chronology constraining the timeframe of island accumulation. Detailed chronostratigraphic studies alongside improved resolution of mid- to late Holocene sea-level change will refine the specific relationship between island formation and sealevel change and provide insights into potential future responses.

2. We argue that carbonate budget studies are essential to better understand the dynamics of reefs and islands, and to model the effects of climate change. While carbonate production processes are broadly understood, contemporary analyses of carbonate production and sediment generation rates are lacking. Such information is of critical importance to understanding whether islands are connected to ongoing supplies of sediment or are built of relict reservoirs of sediment. Such differences will influence the future morphological trajectory of islands and influence the availability of aggregates for local communities.

3. Early investigations of the islands of Spermonde (Umbgrove, 1929 , 1930) generated detailed maps of island shape and location. There is significant potential through the use of aerial photographic and satellite imagery to resolve the magnitude, rates and styles of island change across the archipelago. Such a dataset has the potential to be the second longest in temporal length and would be an invaluable addition to the growing data on island change from the different reef seas. 
4. Improved resolution of the reef surface hydrodynamic processes, the resultant three-dimensional flows and sediment fluxes are fundamental for a more rigorous theoretical understanding of island dynamics, for development of geomorphic models of landform change and to underpin practical coastal management strategies. Of note, the crossshelf energy gradient provides a laboratory to isolate the influence of storms climate and potentially sea-level change on island dynamics.

\section{AUTHOR CONTRIBUTIONS}

Both authors were equally involved in the conceptual design and writing of the manuscript.

\section{REFERENCES}

Albert, S., Leon, J. X., Grinham, A. R., Church, J. A., Gibbes, B. R., and Woodroffe, C. D. (2016). Interactions between sea-level rise and wave exposure on reef island dynamics in the Solomon Islands. Environ. Res. Lett. 11:54011. doi: 10.1088/1748-9326/11/5/054011

Barnett, J., and Adger, W. N. (2003). Climate dangers and atoll countries. Clim. Change 61, 321-337. doi: 10.1023/B:CLIM.0000004559.08755.88

Bayliss-Smith, T. P. (1988). The role of hurricanes in the development of reef Islands, Ontong Java Atoll, Solomon Islands. Geogr. J. 154, 377-391. doi: $10.2307 / 634610$

Bergman, S. C., Coffield, D. Q., Talbot, J. P., and Garrard, R. A. (1996). Tertiary tectonic and magmatic evolution of western Sulawesi and the Makassar Strait, Indonesia: evidence for a Miocene continent-continent collision. Geol. Soc. London Spec. Publ. 106, 391-429. doi: 10.1144/GSL.SP.1996. 106.01 .25

Bird, P. (2003). An updated digital model of plate boundaries. Geochem. Geophys. Geosyst. 4, 1-52. doi: 10.1029/2001GC000252

Blumenstock, D. I. (1958). Typhoon effects at Jaluit atoll in the Marshall Islands. Nature 182, 1267-1269. doi: 10.1038/1821267a0

Blumenstock, D. I., Fosberg, F. R., and Johnson, C. G. (1961). The re-survey of typhoon effects on Jaluit Atoll in the Marshall Islands. Nature 189, 618-620. doi: $10.1038 / 189618 \mathrm{a} 0$

Brander, R. W., Kench, P. S., and Hart, D. (2004). Spatial and temporal variations in wave characteristics across a reef platform, Warraber Island, Torres Strait, Australia. Mar. Geol. 207, 169-184. doi: 10.1016/j.margeo.2004.03.014

Cowell, P., and Thom, B. G. (1994). "Morphodynamics of coastal Evolution Chapter 2," in Coastal Evolution: Late Quaternary Shoreline Morphodynamics, eds R. W. G. Carter and C. D. Woodroffe (Cambridge: Cambridge University Press), 33-83.

Dawson, J. L., and Smithers, S. G. (2010). Shoreline and beach volume change between 1967 and 2007 at Raine Island, Great Barrier Reef, Australia. Glob. Planet. Change 72, 141-154. doi: 10.1016/j.gloplacha.2010.01.026

De Boer, B., Lourens, L. J., and van de Wal, R. S. W. (2014a). Persistent 400,000-year variability of Antarctic ice volume and the carbon cycle is revealed throughout the Plio-Pleistocene. Nat. Commun. 5:2999. doi: $10.1038 /$ ncomms3999

De Boer, B., Stocchi, P., and van de Wal, R. S. W. (2014b). A fully coupled 3-D ice-sheet-sea-level model: algorithm and applications. Geosci. Model Dev. 7, 2141-2156. doi: 10.5194/gmd-7-2141-2014

De Klerk, L. G. (1982). Zeespiegel Riffen en Kustflakten in zuidwest Sulawesi, Indonesia. Utrecht Geogr. Stud. 27, 1-172.

Dickinson, W. (1999). Holocene sea-level record on Funafuti and potential impact of global warming on central Pacific atolls. Quat. Res. 51, 124-132. doi: 10.1006/qres.1998.2029

Duvat, V. K. E., and Pillet, V. (2017). Shoreline changes in reef islands of the Central Pacific: Takapoto Atoll, Northern Tuamotu, French Polynesia. Geomorphology 282, 96-118. doi: 10.1016/j.geomorph.2017.01.002

\section{ACKNOWLEDGMENTS}

We thank Therese Tangermann for GIS assistance during the preparation of Figure 2. The publication of this article was financed through the Open Access Fund of ZMT.

\section{SUPPLEMENTARY MATERIAL}

The Supplementary Material for this article can be found online at: http://journal.frontiersin.org/article/10.3389/fmars. 2017.00145/full\#supplementary-material

Supplementary Image 1 | Bathymetric map of the Spermonde Archipelago, Indonesia, showing larger reef islands and shallow-marine reef structures.

Edinger, E. N., Jompa, J., Limmon, G. V., Widjatmoko, W., and Risk, M. J. (1998). Reef degradation and coral biodiversity in Indonesia: effects of land-based pollution, destructive fishing practices and changes over time. Mar. Pollut. Bull. 36, 617-630. doi: 10.1016/S0025-326X(98)00047-2

Erftemeijer, P. L. A. (1993). Factors Limiting Growth and Production of Tropical Seagrasses: Nutrient Dynamics in Indonesian Seagrass Beds. [dissertation], University of Bremen, Nijmegen.

Ferris, E., Cernea, M. M., and Petz, D. (2011). On the Front Line of Climate Change and Displacement: Learning from and with Pacific Island Countries. Washington, DC: Brokings Institution.

Ferrol-Schulte, D., Gorris, P., Baitoningsih, W., Adhuri, D. S., and Ferse, S. C. A. (2015). Coastal livelihood vulnerability to marine resource degradation: a review of the Indonesian national coastal and marine policy framework. Mar. Policy 52, 163-171. doi: 10.1016/j.marpol.2014.09.026

Ferse, S., Glaser, M., Schultz, C., and Jamaluddin, J. (2012). "Linking research to Indonesia's CTI action plan: the SPICE program," in Proceedings of the 12th International Coral Reef Symposium (Cairns, QLD), 9-13.

Flood, P. G. (1986). Sensitivity of coral cays to climate variations, southern Great Barrier Reef, Australia. Coral Reefs 5, 13-18. doi: 10.1007/BF00302166

Ford, M. R. (2011). Shoreline changes on an urban atoll in the central Pacific Ocean: Majuro Atoll, Marshall Islands. J. Coast. Res. 28, 11-22. doi: 10.2112/JCOASTRES-D-11-00008.1

Ford, M. R. (2013). Shoreline changes interpreted from multi-temporal aerial photographs and high resolution satellite images: Wotje Atoll, Marshall Islands. Remote Sens. Environ. 135, 130-140. doi: 10.1016/j.rse.2013.03.027

Ford, M. R., and Kench, P. S. (2014). Formation and adjustment of typhoon-impacted reef islands interpreted from remote imagery: Nadikdik Atoll, Marshall Islands. Geomorphology 214, 216-222. doi: 10.1016/j.geomorph.2014.02.006

Ford, M. R., and Kench, P. S. (2016). Spatiotemporal variability of typhoon impacts and relaxation intervals on Jaluit Atoll, Marshall Islands. Geology 44:G37402.1. doi: 10.1130/G37402.1

Glaser, M., Breckwoldt, A., Deswandi, R., Radjawali, I., Baitoningsih, W., and Ferse, S. C. A. (2015). Of exploited reefs and fishers-A holistic view on participatory coastal and marine management in an Indonesian archipelago. Ocean Coast. Manag. 116, 193-213. doi: 10.1016/j.ocecoaman.2015.07.022

Gordon, A. L. (2005). Oceanography of the Indonesian seas and their throughflow. Oceanography 18, 14-27. doi: 10.5670/oceanog.2005.01

Gordon, A. L., Susanto, R., and Dwi, F. A. (1999). Throughflow within Makassar Strait. Geophys. Res. Lett. 26, 3325-3328. doi: 10.1029/1999GL002340

Gordon, A. L., Susanto, R., and Dwi, V. K. (2003). Cool Indonesian throughflow as a consequence of restricted surface layer flow. Nature 425, 824-828. doi: $10.1038 /$ nature02038

Gourlay, M. R. (1988). "Coral cays: products of wave action and geological processes in a biogenic environment," in Proceedings of the Sixth International Coral Reef Symposium, Vol. 2, Contributed Papers, eds J. H. Choat, D. Barnes, M. A. Borowitzka, J. C. Coll, P. J. Davies, P. Flood, B. G. Hatcher, D. Hopley, P. A. Hutchings, D. Kinsey, G. R. Orme, M. Pichon, P. F. Sale, P. Sammarco, 
C. C. Wallace, C. Wilkinson, E. Wolanski, and O. Bellwood (Townsville, QLD), 491-496.

Gourlay, M. R. (2011). "Wave shoaling and refraction," in Encyclopedia of Modern Coral Reefs, ed D. Hopley (Dordrecht: Springer), 1149-1154. doi: 10.1007/ 978-90-481-2639-2_164

Green, M. (2016). Contested territory. Nat. Clim. Chang. 6, 817-820. doi: $10.1038 /$ nclimate 3112

Hall, R. (1997). Cenozoic plate tectonic reconstructions of SE Asia. Geol. Soc. London, Spec. Publ. 126, 11-23. doi: 10.1144/GSL.SP.1997.126.01.03

Hall, R., and Blundell, D. J. (1996). Tectonic Evolution of Southeast Asia. London, UK: Geological Society of America. doi: 10.1144/GSL.SP.1996.106.01.01

Hamilton, W. B. (1979). Tectonics of the Indonesian Region. Available online at: http://pubs.er.usgs.gov/publication/pp1078

Harmelin-Vivien, M. L. (1994). The effects of storms and cyclones on coral reefs: a review. J. Coast. Res. 211-231.

Haya, L. O. M. Y., and Fujii, M. (2017). Mapping the change of coral reefs using remote sensing and in situ measurements: a case study in Pangkajene and Kepulauan Regency, Spermonde Archipelago, Indonesia. J. Oceanogr. 1-23. doi: 10.1007/s10872-017-0422-4

Hayne, M., and Chappell, J. (2001). Cyclone frequency during the last 5000 years at Curacao Island, north Queensland, Australia. Palaeogeogr. Palaeoclimatol. Palaeoecol. 168, 207-219. doi: 10.1016/S0031-0182(00)00217-0

Hopley, D. (1978). "Wheeler reef: cay mobility," in Geographical Studies of the Townsville Area, James Cook University of North Queensland Monograph Series Occasional Paper, Vol. 2, ed D. Hopley (Townsville, QLD: James Cook University of North Queensland), 55-58. 55 Ü58.

Hubbard, D., Gischler, E., Davies, P., Montaggioni, L., Camoin, G., Dullo, W.-C., et al. (2014). Island outlook: warm and swampy. Science (New York, NY) 345, 1461. doi: 10.1126/science.345.6203.1461-a

Janßen, A., Wizemann, A., Klicpera, A., Satari, D. Y., Westphal, H., and Mann, T. (2017). Sediment composition and facies of coral reef islands in the Spermonde Archipelago, Indonesia. Front. Mar. Sci. 4:144. doi: 10.3389/fmars.2017. 00144

Jompa, J. (1996). Monitoring and Assessment of Coral Reefs in Spermonde Archipelago, South Sulawesi [dissertation]. McMaster University, Hamilton.

Katili, J. A. (1978). Past and present geotectonic position of Sulawesi, Indonesia. Tectonophysics 45, 289-322. doi: 10.1016/0040-1951(78)90166-X

Kench, P. S., and Brander, R. (2006b). Response of reef island shorelines to seasonal climate oscillations: South Maalhosmadulu atoll, Maldives. J. Geophys. Res. 111, 1-12. doi: 10.1029/2005JF000323

Kench, P. S. (2013). "Coral systems," in Treatise on Geomorphology, Vol 10, Coastal Geomorphology, eds J. F. Shroder (Editor-in-chief) and D. J. Sherman (Volume Editor) (San Diego, CA: Academic Press), 328-359.

Kench, P. S., and Brander, R. W. (2006a). Wave processes on coral reef flats: implications for reef geomorphology using Australian case studies. J. Coast. Res. 22, 209-223. doi: 10.2112/05A-0016.1

Kench, P. S., Brander, R. W., Parnell, K. E., and McLean, R. F. (2006a). Wave energy gradients across a Maldivian atoll: implications for island geomorphology. Geomorphology 81, 1-17. doi: 10.1016/j.geomorph.2006.03.003

Kench, P. S., Brander, R. W., Parnell, K. E., and O'Callaghan, J. M. (2009b). Seasonal variations in wave characteristics around a coral reef island, South Maalhosmadulu atoll, Maldives. Mar. Geol. 262, 116-129. doi: 10.1016/j.margeo.2009.03.018

Kench, P. S., Chan, J., Owen, S. D., and McLean, R. F. (2014a). The geomorphology, development and temporal dynamics of Tepuka Island, Funafuti atoll, Tuvalu. Geomorphology 222, 46-58. doi: 10.1016/j.geomorph.2014.03.043

Kench, P. S., McLean, R. F., Brander, R. W., Nichol, S. L., Smithers, S. G., Ford, M. R., et al. (2006b). Geological effects of tsunami on mid-ocean atoll islands: the Maldives before and after the Sumatran tsunami. Geology 34, 177-180. doi: 10.1130/G21907.1

Kench, P. S., McLean, R. F., and Nichol, S. L. (2005). New model of reef-island evolution: Maldives, Indian Ocean. Geology 33, 145-148. doi: $10.1130 / \mathrm{G} 21066.1$

Kench, P. S., Nichol, S. L., Smithers, S. G., McLean, R. F., and Brander, R. W. (2008). Tsunami as agents of geomorphic change in mid-ocean reef islands. Geomorphology 95, 361-383. doi: 10.1016/j.geomorph.2007.06.012
Kench, P. S., Owen, S. D., and Ford, M. R. (2014b). Evidence for coral island formation during rising sea level in the central Pacific Ocean. Geophys. Res. Lett. 820-827. doi: 10.1002/2013GL059000

Kench, P. S., Parnell, K. E., and Brander, R. W. (2009c). Monsoonally influenced circulation around coral reef islands and seasonal dynamics of reef island shorelines. Mar. Geol. 266, 91-108. doi: 10.1016/j.margeo.2009.07.013

Kench, P. S., Smithers, S. G., and McLean, R. F. (2012). Rapid reef island formation and stability over an emerging reef flat: Bewick Cay, northern Great Barrier Reef, Australia. Geology 40, 347-350. doi: 10.1130/G32816.1

Kench, P. S., Smithers, S. L., McLean, R. F., and Nichol, S. L. (2009a). Holocene reef growth in the Maldives: evidence of a mid-Holocene sea level highstand in the central Indian Ocean. Geology 37, 455-458. doi: 10.1130/G25590A.1

Kench, P. S., Thompson, D., Ford, M. R., Ogawa, H., and McLean, R. F. (2015). Coral islands defy sea-level rise over the past century: Records from a central Pacific atoll. Geology 43:515. doi: 10.1130/g36555.1

Klepp, S. (2014). "Small island states and the new climate change movement: the case of Kiribati," in Routledge Handbook of the Climate Change Movement, eds M. Dietz and H. Garrelts (London, New York: Routledge), 308-319.

Kuenen, P. H. (1934). Geology of Coral Reefs. Wetenschappelijke Uitkomsten der Snellius-Expeditie. Geol. Mag. 71, 477-478.

Lambeck, K. (1998). On the choice of timescale in glacial rebound modelling: mantle viscosity estimates and the radiocarbon timescale. Geophys. J. Int. 134, 647-651. doi: 10.1046/j.1365-246x.1998.00597.x

Leatherman, S. P., and Beller-Simms, N. (1997). Sea-level rise and small island states: an overview. J. Coast. Res. 1-16.

Lee, T. T., and Black, K. P. (1978). "The energy spectra of surf waves on a coral reef," in Proceedings of the 16th International Conference on Coastal Engineering ASCE (Hamburg), 588-608. doi: 10.1061/9780872621909.035

Lowe, R. J., Falter, J. L., and Bandet, M. D. (2005). Spectral wave dissipation over a barrier reef. J. Geophys. Res. 110:C04001. doi: 10.1029/2004JC002711

Mandlier, P. G., and Kench, P. S. (2012). Analytical modeling of wave refraction and convergence on coral reef platforms: implications for island formation and stability. Geomorphology, 159-160, 84-92. doi: 10.1016/j.geomorph.2012.03.007

Mann, T. (2015). Reef Island Dynamics on Recent-Past and Geological Timescales: New Insights from the Indo-Pacific region [dissertation]. University of Bremen, Bremen.

Mann, T., Bayliss-Smith, T., and Westphal, H. (2016b). A Geomorphic Interpretation of Shoreline Change Rates on Reef Islands. J. Coast. Res. 32, 500-507. doi: 10.2112/JCOASTRES-D-15-00093.1

Mann, T., Rovere, A., Schöne, T., Klicpera, A., Stocchi, P., Lukman, M., et al. (2016a). The magnitude of a mid-Holocene sea-level highstand in the Strait of Makassar. Geomorphology 257, 155-163. doi: 10.1016/j.geomorph.2015. 12.023

Mann, T., and Westphal, H. (2014). Assessing long-term changes in the beach width of Reef Islands based on temporally fragmented remote sensing data. Remote Sens. 6, 6961-6987. doi: 10.3390/rs6086961

Mann, T., and Westphal, H. (2016). Multi-decadal shoreline changes on Takú Atoll, Papua New Guinea: observational evidence of early reef island recovery after the impact of storm waves. Geomorphology 257, 75-84. doi: 10.1016/j.geomorph.2015.12.028

Maragos, J. E., Baines, G. B. K., and Beveridge, P. J. (1973). Tropical cyclone bebe creates a new land formation on funafuti atoll. Science 181, 1161-1164. doi: 10.1126/science.181.4105.1161

McKoy, H., Kennedy, D. M., and Kench, P. S. (2010). Sand cay evolution on reef platforms, Mamanuca Islands, Fiji. Mar. Geol. 269, 61-73. doi: 10.1016/j.margeo.2009.12.006

McLean, R. F., and Hosking, P. L. (1991). Geomorphology of reef islands and atoll motu in Tuvalu. South Pacific J. Nat. Sci. 11, 167-189.

McLean, R., and Kench, P. (2015). Destruction or persistence of coral atoll islands in the face of 20th and 21st century sea-level rise? Wiley Interdiscipl. Rev. Clim. Change 6, 445-463. doi: 10.1002/wcc.350

Moll, H. (1983). Zonation and Diversity of Scleractinia on Reefs off S. W. Sulawesi, Indonesia [dissertation]. University of Leiden, Amsterdam.

Pala, C. (2014). Warming may not swamp islands. Science 345, 496-497. doi: $10.1126 /$ science.345.6196.496 
Peltier, W. R. (2004). Global glacial isostasy and the surface of the ice-age earth: the ICE-5G (VM2)model and grace. Annu. Rev. Earth Planet. Sci. 32, 111-149. doi: 10.1146/annurev.earth.32.082503.144359

Perry, C. T., Kench, P. S., Smithers, S. G., Riegl, B., Yamano, H., and O’Leary, M. J. (2011). Implications of reef ecosystem change for the stability and maintenance of coral reef islands. Glob. Chang. Biol. 17, 3679-3696. doi: 10.1111/j.1365-2486. 2011.02523.x

Perry, C. T., Kench, P. S., Smithers, S. G., Yamano, H., O’Leary, M., and Gulliver, P. (2013). Time scales and modes of reef lagoon infilling in the Maldives and controls on the onset of reef island formation. Geology 41, 1111-1114. doi: 10.1130/G34690.1

Prasetya, G. S., De Lange, W. P., and Healy, T. R. (2001). The makassar strait tsunamigenic region, Indonesia. Nat. Hazards 24, 295-307. doi: 10.1023/A:1012297413280

Rankey, E. C. (2011). Nature and stability of atoll island shorelines: Gilbert Island chain, Kiribati, equatorial Pacific. Sedimentology 58, 1831-1859. doi: 10.1111/j.1365-3091.2011.01241.x

Ray, R. D., Egbert, G. D., and Erofeeva, S. Y. (2005). Tides in the Indonesian seas. Oceanography 18, 74-79. doi: 10.5670/oceanog.2005.07

Renema, W. (2002). Larger benthic foraminifera as environmental indicators. Scripta Geol. 124, 1-263.

Renema, W., and Troelstra, S. R. (2001). Larger foraminifera distribution on a mesotrophic carbonate shelf in SW Sulawesi (Indonesia). Palaeogeogr. Palaeoclimatol. Palaeoecol. 175, 125-146. doi: 10.1016/S0031-0182(01)00389-3

Roberts, H. H., Murray, S. P., and Suhayda, M. (1977). "Physical processes in a fore-reef shelf environment," in Proceedings of the 3rd International Coral Reef Symposium (Miami), 507-515.

Roberts, H. H., and Suhayda, M. (1983). Wave current interactions on a shallow reef (Nicaragua). Coral Reefs 1, 209-260. doi: 10.1007/BF00304417

Roy, P., and Connell, J. (1991). Climatic change and the future of atoll states. J. Coast. Res. 7, 1057-1075.

Sasajima, S., Nishimura, S., Hirooka, K., Otofuji, Y., Van Leeuwen, T., and Hehuwat, F. (1980). Paleomagnetic studies combined with fission-track datings on the western arc of Sulawesi, East Indonesia. Tectonophysics 64, 163-172. doi: 10.1016/0040-1951(80)90267-X

Smithers, S. G., and Hoeke, R. K. (2014). Geomorphological impacts of highlatitude storm waves on low-latitude reef islands - Observations of the December 2008 event on Nukutoa, Takuu, Papua New Guinea. Geomorphology 222, 106-121. doi: 10.1016/j.geomorph.2014.03.042

Sprintall, J., and Revelard, A. (2014). The Indonesian throughflow response to Indo-Pacific climate variability. J. Geophys. Res. 119, 1161-1175. doi: 10.1002/2013JC009533

Stoddart, D. R. (1963). Effects of Hurricane Hattie on the British Honduras reefs and cays, October 30-31, 1961. Atoll Res. Bull. 95, 1-142. doi: $10.5479 /$ si.00775630.95.1

Stoddart, D. R. (1965). British Honduras cays and the low wooded island problem. Inst. Br. Geogr. Trans. 36, 131-147. doi: 10.2307/621459

Stoddart, D. R. (1971). Coral Reefs and Islands and Catastrophic Storms. London: Macmillan. doi: 10.1007/978-1-349-15424-1_10

Stoddart, D. R., and Steers, J. A. (1977). "The nature and origin of coral reef islands," in Biology and Geology of Coral Reefs, eds $\mathrm{O}$. A. Jones and R. Endean (New York, NY: Academic Press), 59-105. doi: 10.1016/B978-0-12-395528-9.50011-7

Storm, C. (1989). Influences of river systems and coastal hydrodynamics on the water quality during one monsoonal period: a hydrological survey of a tropical coastal area in the Spermonde Archipelago; SW Sulawesi, Indonesia, rapport Geopro, 1989.04. Univ. Utr.

Testut, L., Duvat, V., Ballu, V., Fernandes, R. M. S., Pouget, F., Salmon, C., et al. (2016). Shoreline changes in a rising sea level context: The example of Grande Glorieuse, Scattered Islands, Western Indian Ocean. Acta Oecol. 72, 110-119. doi: 10.1016/j.actao.2015.10.002

Umbgrove, J. H. F. (1929). “The influence of the monsoons on the geomorphology of coral islands," in Proceedings of the 4th Pacific Science Congress, Vol. 2 (Batavia-Bandoeng), 49-54.
Umbgrove, J. H. F. (1930). De koraalriffen van den Spermonde-Archipel (ZuidCelebes). Leidse Geol. Meded. 3, 228-247.

van Bemmelen, R. W. (1949). The Geology of Indonesia. Hague: Gov. Print. Off. Hague.

Verstappen, H. (1954). The influence of climatic change on the formation of coral islands. Am. J. Sci. 252, 428-435. doi: 10.2475/ajs.252.7.428

Wakita, K., and Bambang, W. (1994). Cretaceous radiolarians from the Luk-Ulo melange complex in the Karangsambung area, central Java, Indonesia. J. Southeast Asian Earth Sci. 9, 29-43. doi: 10.1016/0743-9547(94) 90063-9

Walpersdorf, A., Vigny, C., Manurung, P., Subarya, C., and Sutisna, S. (1998). Determining the Sula block kinematics in the triple junction area in Indonesia by GPS. Geophys. J. Int. 135, 351-361. doi: 10.1046/j.1365-246X.1998.00641.x

Webb, A. P., and Kench, P. S. (2010). The dynamic response of reef islands to sealevel rise: evidence from multi-decadal analysis of island change in the Central Pacific. Glob. Planet. Change 72, 234-246. doi: 10.1016/j.gloplacha.2010. 05.003

Wijsman-Best, M., Moll, H., and De Klerk, L. G. (1981). "Present status of the coral reefs in the Spermonde Archipelago (South Sulawesi, Indonesia)," in Proceedings of the 4th International Coral Reef Symposium (Manila), 263-267.

Williams, G. J., Knapp, I. S., Maragos, J. E., and Davy, S. K. (2010). Modeling patterns of coral bleaching at a remote Central Pacific atoll. Mar. Pollut. Bull. 60, 1467-1476. doi: 10.1016/j.marpolbul.2010.05.009

Wizemann, A., Mann, T., Klicpera, A., and Westphal, H. (2015). Microstructural analyses of sedimentary Halimeda segments from the Spermonde Archipelago (SW Sulawesi, Indonesia): a new indicator for sediment transport in tropical reef islands? Facies 61:4. doi: 10.1007/s10347-015-0429-5

Woodley, J. D. (1980). Hurricane Allen destroys Jamaican coral reefs. Nature 287, 387. doi: $10.1038 / 287387 \mathrm{a} 0$

Woodley, J. D., Chornesky, E. A., Cliffo, P. A., Jackson, J. B. C., Kaufman, L. S., Knowlton, N., et al. (1981). Hurricane Allen's Impact o Jamaican Coral Reef. Science 214, 13. doi: 10.1126/science.214.4522.749

Woodroffe, C. D. (2008). Reef-island topography and the vulnerability of atolls to sea-level rise. Glob. Planet. Change 62, 77-96. doi: 10.1016/j.gloplacha.2007.11.001

Woodroffe, C. D., McLean, R. F., Smithers, S. G., and Lawson, E. M. (1999). Atoll reef-island formation and response to sea-level change: West Island, Cocos (Keeling) Islands. Mar. Geol. 160, 85-104. doi: 10.1016/S0025-3227(99)0 0009-2

Woodroffe, C. D., and Morrison, R. J. (2001). Reef-island accretion and soil development, Makin Island, Kiribati, central Pacific. Catena 44, 245-261. doi: 10.1016/S0341-8162(01)00135-7

Woodroffe, C. D., Samosorn, B., Hua, Q., and Hart, D. E. (2007). Incremental accretion of a sandy reef island over the past 3000 years indicated by component-specific radiocarbon dating. Geophys. Res. Lett. 34, 1-5. doi: 10.1029/2006GL028875

Yamano, H., Miyajima, T., and Koike, I. (2000). Importance of foraminifera for the formation and maintenance of a coral sand cay: Green Island, Australia. Coral Reefs 19, 51-58. doi: 10.1007/s003380050226

Yates, M. L., Cozannet, L. G., Garcin, M., Sala, E., and Walker, P. (2013). Multidecadal Atoll Shoreline Change on Manihi and Manuae, French Polynesia. J. Coast. Res. 29, 870-882. doi: 10.2112/jcoastres-d-12-00129.1

Conflict of Interest Statement: The authors declare that the research was conducted in the absence of any commercial or financial relationships that could be construed as a potential conflict of interest.

Copyright (c) 2017 Kench and Mann. This is an open-access article distributed under the terms of the Creative Commons Attribution License (CC BY). The use, distribution or reproduction in other forums is permitted, provided the original author(s) or licensor are credited and that the original publication in this journal is cited, in accordance with accepted academic practice. No use, distribution or reproduction is permitted which does not comply with these terms. 